\title{
A PROTEÇÃO JURÍDICA DO USUÁRIO DE SERVIÇO PÚBLICO ENTRE O DIREITO ADMINISTRATIVO E O CÓDIGO DE DEFESA DO CONSUMIDOR: A NECESSIDADE DE UMA FILTRAGEM CONSTITUCIONAL ${ }^{1}$
}

\author{
THE LEGAL PROTECTION OF THE PUBLIC SERVICE USER BETWEEN \\ ADMINISTRATIVE LAW AND THE CONSUMER PROTECTION CODE: THE \\ REQUIREMENT OF A CONSTITUTIONAL FILTERING
}

\begin{abstract}
Daniel Wunder Hachem
Professor dos Cursos de Graduação, Mestrado e Doutorado em Direito da Pontifícia Universidade Católica do Paraná e da Universidade Federal do Paraná (Curitiba-PR, Brasil). Doutor e Mestre em Direito do Estado pela Universidade Federal do Paraná.

Professor do Corpo Docente Estável do Mestrado em Direito Administrativo da Universidad Nacional del Litoral (Argentina). Professor Visitante da Universidad Rovira i Virgili (Espanha). Diretor Acadêmico do NINC - Núcleo de Investigações Constitucionais do PPGD-UFPR (www.ninc.com.br). Více-Líder do NUEPD - Núcleo de Pesquisas em

Políticas Públicas e Desenvolvimento Humano do PPGD-PUCPR. Coordenador Executivo, pelo Brasil, da Rede Docente Eurolatinoamericana de Derecho Administrativo. Membro do Foro Iberoamericano de Derecho Administrativo e da Asociación de Derecho Público del Mercosur. Editor Acadêmico da A\&C - Revista de Direito Administrativo e

Constitucional. Coordenador Editorial da Revista Eurolatinoamericana de Derecho Administrativo (UNL) e da Revista de Investigações Constitucionais (UFPR). Coeditor da Revista de Direito Econômico e Socioambiental (PUCPR). Advogado. E-mail: danielhachem@gmail.com
\end{abstract}

Luzardo Faria

Acadêmico de Direito da Universidade Federal do Paraná. Pesquisador do NINC - Núcleo de Investigações Constitucionais do Programa de Pós-Graduação em Direito da UFPR. Foi pesquisador-bolsista do PIBIC - Programa Institucional de Bolsas de Iniciação

Científica/CNPq (2013-2015) e monitor das disciplinas de Teoria do Estado e Ciência Política (2013), Direito Administrativo A (2015) e Direito Administrativo B (2016) pelo PID - Programa de Iniciação à Docência. Secretário Executivo da Revista de Investigações Constitucionais. E-mail: farialuzardo@hotmail.com.

Recebido em: 20/08/2016

Aprovado em: 28/09/2016

Doi: $10.5585 / \mathrm{rdb} . v 15 i 6.485$

RESUMO: Diante da ausência de uma lei específica para a proteção de usuários de serviços públicos, é muito comum que o Código de Defesa do Consumidor seja aplicado nessas situações. As justificativas para legitimar essa aplicação são ainda mais fortes quando se analisa o atual regime jurídico da prestação de serviços públicos, cada vez mais influenciado por normas tidas como de "Direito Privado". Qualquer solução extremada (tanto a aplicação total, como a negação da aplicação do CDC) deve ser afastada, tendo em vista a necessidade de uma proteção jurídica

\footnotetext{
${ }^{1}$ Pesquisa desenvolvida no marco do projeto de pesquisa internacional financiado pela "Convocatoria de Estancia como Profesor Visitante n. EL004674”, Departamento de Dret Públic, Universitat Rovira i Virgili (Tarragona, Espanha), promovido em conjunto pelo NUPED - Núcleo de Pesquisas em Políticas Públicas e Desenvolvimento Humano do Programa de Pós-Graduação em Direito da Pontifícia Universidade Católica do Paraná.
}

Revista de Direito Brasileira | São Paulo, SP | v. 15 | n. 6 | p. 311 - 336 | set./dez. 2016 
adequada dos usuários de serviços públicos. Nesse sentido, defende-se a aplicação provisória das normas do CDC sempre que, passando pela filtragem constitucional, esses dispositivos estejam de acordo com o regime jurídico-administrativo.

Palavras-chave: Usuário de serviço público; Proteção Jurídica; Código de Defesa do Consumidor; Filtragem constitucional; Regime jurídico-administrativo.

ABSTRACT: In the absence of a specific statute for the protection of public service users, the application of the Consumer Protection Code (CDC) is very common. The justification to legitimize this application is even stronger when considered the current legal regime for the provision of public services, increasingly influenced by rules taken as "private law". Any extreme solution (either the full application or the denial of the application of the CDC) must be rejected, considering the need of an adequate legal protection of public service users. In this regard, the article supports the provisional application of the CDC norms in the cases in which, through constitutional filtering, these rules are in accordance with the administrative legal regime.

Keywords: Public service user; Legal protection; Consumer Protection Code; Constitutional filtering; Legal administrative regime.

SUMÁRIO: Introdução; 1. A noção jurídico-constitucional de serviço público no Direito brasileiro contemporâneo; 2. A influência da lógica consumerista no Direito dos Serviços Públicos contemporâneo; 3. O beneficiário de serviço público para o Direito: usuário-cidadão ou consumidor-cliente? 4. A impropriedade de uma divisão estanque entre o Direito Público e o Direito Privado e o regime jurídico aplicável aos usuários de serviços públicos: o Direito como um todo indivisível; 5. As possíveis situações e métodos de aplicação do Código de Defesa do Consumidor às relações de serviço público: a necessidade de filtragem constitucional; 6. Os limites à utilização indiscriminada do CDC aos serviços públicos: casos de inaplicabilidade em face de óbices constitucionais; Conclusões; Referências.

\section{INTRODUÇÃO}

O tema da aplicabilidade do Código de Defesa do Consumidor nas relações que envolvem prestação de serviços públicos suscita divergências no Direito brasileiro. No âmbito doutrinário é possível encontrar desde correntes que sustentam a plena incidência do CDC nessas relações, até posições que defendem a total inaplicabilidade de tal diploma normativo na seara dos serviços públicos. $\mathrm{O}$ assunto, no entanto, não se limita a uma querela acadêmica. A depender do entendimento adotado, as consequências na vida do cidadão usuário de serviços públicos tais como saneamento básico, energia elétrica, transporte coletivo, educação e saúde - poderão ser muito impactantes, gerando uma tutela mais ampla ou mais reduzida da sua esfera de direitos fundamentais.

A controvérsia se tornou ainda mais acirrada com o art. 27 da Emenda Constitucional $n^{\circ}$ 19/1998, o qual endereça ao Poder Legislativo o dever constitucional de elaborar uma lei própria à defesa do usuário de serviços públicos. Surge então a dúvida: se a Constituição da República exige a criação de uma lei própria para a proteção dos cidadãos que usufruem de serviços públicos, seria essa uma razão para rejeitar a aplicação do CDC a essas relações jurídicas? Diante da ausência de criação dessa lei, tal raciocínio não implicaria reduzir a tutela desses cidadãos ao afastar a possibilidade de invocar em seu favor uma lei bastante protetiva?

A temática da incidência do CDC nos casos de prestação de serviços públicos não pode ser pensada de forma mecânica a partir de uma lógica binária de divisão estanque e dicotômica do ordenamento jurídico em Direito Público e Direito Privado, reputando o Código de Defesa do 
Consumidor como lei inerente a essa última esfera e, por isso, inaplicável às situações que envolvem o Poder Público. É preciso encarar o tema à luz das normas inseridas na ordem constitucional para se chegar a uma solução que esteja de acordo com o grau de proteção conferido ao cidadão pela Constituição da República, por meio de uma interpretação sistemática.

É o que se pretende desenvolver nas próximas páginas: uma análise da possibilidade de aplicação do CDC às relações que envolvem a prestação de serviços públicos, a partir de uma leitura constitucional.

\section{A NOÇÃO JURÍDICO-CONSTITUCIONAL DE SERVIÇO PÚBLICO NO DIREITO BRASILEIRO CONTEMPORÂNEO}

O primeiro ponto a ser analisado, antes de se enfrentar a questão da aplicabilidade do Código de Defesa do Consumidor aos serviços públicos, consiste no significado técnico-jurídico da expressão "serviço público" no Direito brasileiro, para que se delimite com rigor científico o objeto de análise deste estudo. ${ }^{2}$

O Direito positivo brasileiro não defina textualmente o que significa serviço público. A explicação sobre o significado dessa atividade desenvolvida pelo Estado é elaborada pela doutrina, e pode ser realizada a partir da conjugação de seus aspectos materiais (traços intrínsecos à própria atividade) e jurídicos (regime de princípios e regras sobre ela incidentes). A partir do ponto de vista material, os serviços públicos consistem em espécie de atividade econômica em sentido amplo. Esta se caracteriza pela produção, circulação e comercialização de bens e serviços de natureza econômica, isto é, de "objetos relativamente escassos, suscetíveis de posse e que servem, direta ou indiretamente, para a satisfação de necessidades humanas". ${ }^{3}$ São marcados notadamente pela sua utilidade (satisfazem necessidades do ser humano) e escassez (não se encontram na natureza em abundância e facilmente sujeitos à apropriação). ${ }^{4}$ Atividades como os serviços de educação, saúde, transporte, fornecimento de energia elétrica, abastecimento de água potável, entre tantas outras são peculiarizadas por essas notas. Independentemente de quem esteja autorizado a prestá-las (Estado ou sujeitos privados) e sob qual regime jurídico (mais ou menos benéfico ao destinatário), são serviços que envolvem bens escassos e úteis, e, portanto, representam atividade de caráter econômico. ${ }^{5}$

Sob tal perspectiva - material - é possível afirmar que o gênero "atividades econômicas em sentido amplo" engloba como espécies tanto os serviços públicos quanto as atividades econômicas em sentido estrito. ${ }^{6}$ São os aspectos jurídicos de cada uma delas, vale dizer, a forma como o Direito as disciplina, que permitem distinguir uma da outra, pois a partir dessa perspectiva elas se diferem expressivamente. ${ }^{7}$ A Constituição brasileira estabelece, em seu art.

\footnotetext{
2 A explicação apresentada neste tópico foi desenvolvida em outro estudo: HACHEM, Daniel Wunder. Direito fundamental ao serviço público adequado e capacidade econômica do cidadão: repensando a universalidade do acesso à luz da igualdade material. A\&C-Revista de Direito Administrativo \& Constitucional. Belo Horizonte, ano 14, n. 55, p. 123-158, jan./mar. 2014.

${ }^{3}$ GASTALDI, José Pretelli. Elementos de economia política. 17. ed. São Paulo: Saraiva, 1999. p. 88.

${ }^{4}$ NUSDEO, Fábio. Curso de economia: introdução ao Direito Econômico. São Paulo: Revista dos Tribunais, 1997. p. 34.

${ }^{5}$ GABARDO, Emerson. Interesse público e subsidiariedade: o Estado e a sociedade civil para além do bem e do mal. Belo Horizonte: Fórum, 2009. p. 130 et seq.

${ }^{6}$ GRAU, Eros Roberto. A ordem econômica da Constituição de 1988: interpretação e crítica. 14. ed. São Paulo: Malheiros, 2010. p. 101.

${ }^{7}$ Ricardo Marcondes Martins discorda da classificação que considera o serviço público uma espécie de atividade econômica em sentido amplo, apresentando três fundamentos para embasar sua divergência. Os três são de ordem jurídica, não material: sustenta a incompatibilidade da atividade de "serviço público" com três princípios regentes das atividades econômicas (livre concorrência, propriedade privada e defesa do consumidor). Ocorre que o regime jurídico incidente - argumento sobre o qual se apoia o autor para distinguir "serviço público" de "atividade Revista de Direito Brasileira | São Paulo, SP | v. 15 | n. 6 | p. 311 - 336 | set./dez. 2016
} 
173, caput, que a exploração direta das atividades econômicas (em sentido estrito) está reservada à iniciativa privada, de modo que o seu desenvolvimento não constitui tarefa típica do Estado, sendo-lhe permitido realizá-las somente em hipóteses excepcionais. ${ }^{8}$

Já os serviços públicos constituem atividades econômicas lato sensu cuja prestação, em virtude de uma decisão estatal consolidada pelo ordenamento jurídico, é considerada atribuição típica do Poder Público, a quem incumbe o dever de garantir que serão oferecidas continuamente à população e sob a incidência de um regime principiológico peculiar de bases juspublicistas. São atividades econômicas (lato sensu) como quaisquer outras, que em princípio poderiam ser livremente exploradas pela iniciativa privada sob o regime de mercado, mas que o Estado reputou demasiadamente importantes para a satisfação de relevantes necessidades humanas que seria inadequado correr o risco de que elas deixassem de ser ofertadas pelos particulares ou de que se tornassem inacessíveis a uma parcela da população que delas necessitasse. ${ }^{9}$ Assim, através de normas jurídicas primárias atributivas de deveres-poderes às entidades estatais, o Poder Público dirige à Administração a obrigação de assegurar que tais atividades sejam prestadas permanentemente, estipulando princípios de observância obrigatória sobre elas incidentes para atingir a finalidade de que todos os cidadãos que delas necessitem possam acedê-las de maneira igualitária.

Essa intelecção se deduz do art. 175 da Constituição. O caput do dispositivo estabelece que "incumbe ao Poder Público, na forma da lei, diretamente ou sob regime de concessão ou permissão, sempre através de licitação, a prestação de serviços públicos”. Atualmente, boa parte dos serviços públicos no Brasil são concedidos à iniciativa privada, ${ }^{10}$ por meio de um contrato administrativo, regido pela Lei $\mathrm{n}^{\circ} 8.987 / 95$ ou pela Lei $\mathrm{n}^{\circ} 11.079 / 04$, com o qual o particular compromete-se a prestar determinado serviço público, em nome próprio, por sua conta e risco, nas condições fixadas unilateralmente pela Administração Pública, sob a garantia do equilíbrio econômico-financeiro desse contrato, remunerando-se (i) seja pelas tarifas cobradas dos usuários (concessão comum), (ii) seja por essas tarifas e por um valor pago diretamente pelo Poder Público (concessão patrocinada), (iii) seja simplesmente pela contraprestação pecuniária do Poder Público (concessão administrativa). ${ }^{11}$ Por esse motivo, ao se estudar a questão da aplicabilidade do $\mathrm{CDC}$ às relações de serviços públicos deve-se sempre ter em mente as peculiaridades atinentes ao modelo de prestação pelo regime de concessão.

Perceba-se que a ideia de exclusividade da titularidade das atividades que o sistema normativo considera serviços públicos não é um traço que marca a sua definição. ${ }^{12}$ É certo que a

econômica" - é justamente o critério que diferencia essas duas modalidades de atividade econômica lato sensu. O que as assemelha, tornando-as espécies do mesmo gênero, é o seu objeto: produção e circulação de bens econômicos (escassos, úteis e tendentes à satisfação de necessidades humanas). Os princípios que as regem constituem, de fato, o fator que as diferencia completamente. MARTINS, Ricardo Marcondes. Regulação administrativa à luz da Constituição Federal. São Paulo: Malheiros, 2011. p. 197-198.

${ }^{8}$ Constituição da República Federativa do Brasil (1988): “Art. 173. Ressalvados os casos previstos nesta Constituição, a exploração direta de atividade econômica pelo Estado só será permitida quando necessária aos imperativos da segurança nacional ou a relevante interesse coletivo, conforme definidos em lei".

${ }^{9}$ O Poder Público percebe, nas palavras de Augusto Neves Dal Pozzo, que aquela "atividade resulta primordial para a satisfação das necessidades sociais, não sendo possível oferecê-la sob a égide das leis de mercado". DAL POZZO, Augusto Neves. Aspectos fundamentais do serviço público no Direito brasileiro. São Paulo: Malheiros, 2012. p. 117.

${ }^{10}$ Para uma análise acerca dos principais motivos que levam à necessidade de concessão de serviços públicos no Brasil, principalmente em relação às parcerias público-privadas, ver: BELEM, Bruno Moraes Faria Monteiro. A concessão administrativa nos serviços de relevância social. A\&C - Revista de Direito Administrativo \& Constitucional, Belo Horizonte, ano 11, n. 44, p. 165-190, abr./jun. 2011.

${ }^{11}$ MELLO, Celso Antônio Bandeira de. Curso de Direito Administrativo. 31. ed. São Paulo: Malheiros, 2014. p. 719-720.

${ }^{12}$ A esse respeito, ver: SCHIRATO, Vitor Rhein. Livre iniciativa nos serviços públicos. Belo Horizonte: Fórum, 2012; MENEGAT, Fernando. Serviço público e concorrência: ensaio para uma quebra do princípio da titularidade estatal exclusiva. A\&C - Revista de Direito Administrativo \& Constitucional, Belo Horizonte, ano 12, n. 49, p. 207246, jul./set. 2012.

Revista de Direito Brasileira | São Paulo, SP | v. 15 | n. 6 | p. 311 - 336 | set./dez. 2016 
titularidade da atividade enquanto serviço público será exclusiva do Estado, pois se o ordenamento jurídico obrigá-lo a prestá-la ele não poderá se desincumbir de proporcionar a sua oferta contínua sob um regime jurídico especial. Mas casos há em que a Constituição autoriza que aquela mesma atividade que compete ao Estado prestar na condição de serviço público seja explorada pela iniciativa privada na condição de atividade econômica em sentido estrito (ainda que em tais casos ela seja fortemente regulada pelo Estado e o regime sofra o influxo de alguns princípios de Direito Público). ${ }^{13}$

A partir dessas considerações se depreende que o serviço público é composto por três elementos: (i) o subjetivo, que consiste na titularidade do Estado, a quem cabe assegurar continuamente a sua prestação, fornecendo-os diretamente ou através de sujeitos privados por via da concessão ou da permissão; (ii) o material (ou objetivo), que diz respeito ao fato de se tratar de uma atividade de oferecimento de "utilidade ou comodidade material" 14 - isto é, de prestações fáticas - e destinada à satisfação de relevantes necessidades dos seres humanos, direta ou indiretamente ligadas à garantia e promoção de sua dignidade; ${ }^{15}$ (iii) o formal (ou jurídico), que se refere ao regime jurídico especial ao qual a oferta de tais atividades se submete, composto por princípios e regras de Direito Público, que têm por objetivo garantir a sua prestação adequada, com qualidade e acessibilidade a todos os que deles necessitem. ${ }^{16}$

Feitas essas considerações sobre principais pontos do regime jurídico-constitucional nos serviços públicos no Brasil, passa-se agora à análise das questões que dizem respeito ao problema central desse trabalho.

\section{A INFLUÊNCIA DA LÓGICA CONSUMERISTA NO DIREITO DOS SERVIÇOS PÚBLICOS CONTEMPORÂNEO}

Ao se estudar a inserção de uma lógica de mercado nas relações de serviço público, chega-se à conclusão de que, com esse fenômeno, há uma mudança na lógica integralmente solidária, própria dos serviços públicos, que acaba por alterar o modo de utilização de diversos instrumentos jurídicos dos quais o Estado deve lançar mão para alcançar o interesse público. Essa desfiguração do regime jurídico publicista também gera como consequência a aplicação de normas do Direito do Consumidor aos serviços públicos, uma vez que, com esse cenário, altera-

13 É o que se passa com os serviços de educação, saúde, assistência e previdência, cujo fornecimento obrigatoriamente deverá ser garantido pelo Poder Público, na qualidade de serviços públicos e sob o regime jurídico que lhes é inerente, mas cuja exploração está também autorizada pelos particulares, sob o regime próprio das atividades econômicas stricto sensu (mas parcialmente derrogado por normas juspublicistas) e sob intensa regulação e fiscalização estatal.

${ }^{14}$ MELLO, Celso Antônio Bandeira de. Prestação de serviços públicos e administração indireta. 2. ed. São Paulo: Revista dos Tribunais, 1983. p. 18.

${ }^{15}$ Sobre a relação entre serviços públicos e a concretização do princípio da dignidade da pessoa humana, Maria Sylvia Zanella Di Pietro lembra que "no âmbito do direito administrativo, os temas que mais têm a ver com o respeito à dignidade da pessoa humana, como mínimo existencial, é o referente aos serviços públicos, especialmente os de caráter social, como saúde, educação, previdência, assistência, fundamentalmente.” DI PIETRO, Maria Sylvia Zanella. Direito Administrativo e dignidade da pessoa humana. A\&C - Revista de Direito Administrativo \& Constitucional, Belo Horizonte, ano 13, n. 52, p. 13-33, abr./jun. 2013. p. 21. Romeu Felipe Bacellar Filho também defende uma maior vinculação da atividade administrativa ao princípio constitucional da dignidade da pessoa humana: BACELLAR FILHO, Romeu Felipe. Dignidade da pessoa humana, direitos fundamentais e Direito Administrativo. Revista Eurolatinoamericana de Derecho Administrativo, Santa Fe, vol. 1, n. 2, p. 247-254, jul./dic. 2014.

${ }^{16}$ A formulação aqui apresentada inspira-se no pensamento de Celso Antônio Bandeira de Mello. Ver:. MELLO, Celso Antônio Bandeira de. Serviço público e sua feição constitucional no Brasil. In: CIENFUEGOS SALGADO, David; LÓPEZ OLVERA, Miguel Alejandro (Coords.). Estudios en homenaje a Don Jorge Fernández Ruiz: responsabilidad, contratos y servicios públicos. México: Universidad Autónoma de México, 2005. p. 6-7.

Revista de Direito Brasileira | São Paulo, SP | v. 15 | n. 6 | p. 311 - 336 | set./dez. 2016 
se a posição do Estado na ordem econômica, passando a incidir cada vez mais a lógica própria do livre mercado. ${ }^{17}$

Apesar de se poder perceber duas lógicas diferentes no que se refere ao sistema de prestação de serviços públicos (uma mais influenciada pelo Direito Privado e outra mais pelo Direito Público), deve-se registrar que ambas visam a uma melhor proteção dos cidadãos. O que as diferencia, portanto, é simplesmente o enfoque que dão ao tema: enquanto a visão consumerista intenciona a proteção do usuário per se, individualmente, a publicista busca proteger os cidadãos enquanto membros da coletividade, tendo por objetivo a instituição de um sistema prestacional. ${ }^{18}$

Para melhor compreender esse cenário, deve-se ter em mente a carga histórica do tema analisado. Em um primeiro momento, durante o período de industrialização da sociedade, a padronização das atividades e dos consumidores permitia ao Estado, enquanto organizador e impositor da economia, regulamentar e distribuir o mercado com mais facilidade. No entanto, com o desenvolvimento de uma sociedade fortemente baseada na prestação de serviços esse cenário se altera sensivelmente, erigindo, assim, um novo desafio: satisfazer as necessidades individuais e garantir a harmonia social. ${ }^{19}$ Assim, o usuário foi, por muito tempo, percebido pelo Direito como uma pessoa abstrata, não individualizada, que apenas estava submetido às vontades do administrador público. A abertura dos serviços públicos à concorrência e, com isso, a imposição da figura de usuário-cliente, causou aos poucos a necessidade de instituição de serviços cada vez mais individualizados. ${ }^{20}$

No Brasil da década de 1990, torna-se muito acentuado o fenômeno da liberalização dos serviços públicos. ${ }^{21}$ Com as diversas alterações legislativas levadas à cabo naquela época - em âmbito constitucional e infraconstitucional - para realizar a chamada "reforma do aparelho do Estado", pode-se dizer que passou a existir um clima de concorrência no âmbito dos serviços públicos. Isso fica evidente, por exemplo, com a Lei de Concessão e Permissão de Serviços Públicos (Lei n ${ }^{\circ}$ 8.987/95) que, em seu art. 29, XI, ${ }^{22}$ estabelece como incumbência do Poder Concedente o incentivo à competitividade.

Essa concessão de maior liberdade para atuação dos prestadores privados de serviço público é acompanhada, inevitavelmente, por um afastamento do Poder Público no que se refere à garantia e à promoção dos direitos dos usuários. Logicamente, ao se abrir espaço para a atuação de agentes privados, perde-se espaço público. Ou seja, com a liberalização nas concessões de serviços públicos, reduz-se a garantia estatal de proteção do usuário, ao passo que diminuem as condutas impostas pelo poder concedente às empresas concessionárias. ${ }^{23}$

\footnotetext{
${ }^{17}$ AMAR, Jacques. De l'Usager au Consomatteur de Service Public. Aix-en-Provence: Presses Universitaires d'AixMarseille - PUAM, 2001. p. 31.

${ }_{18}$ ARAGÃO, Alexandre Santos de. Direito dos serviços públicos. 3. ed. Rio de Janeiro: Forense, 2013. p. 476.

${ }^{19}$ RACHLINE, François. Services Publics, Économie de Marché. Paris: Presses de Sciences Po, 1996. p. 89.

20 CHILlON, Sandie. De l'Usager au Consommateur: une évolution de l'ouverture du service public à la concurrence? In: HÉNAFF, Gael (Org.). Concurrence et Services Publics: enjeux et perspectives. Rennes: Presses Universitaires de Rennes - PUR, 2002. p. 288.

${ }^{21}$ Esse movimento também foi sentido em outros países, como se pode depreender da análise de Augusto Durán Martínez sobre o Direito Administrativo uruguaio. MARTÍNEZ, Augusto Durán. Estado Constitucional de Derecho y servicios públicos. A\&C-Revista de Direito Administrativo \& Constitucional, Belo Horizonte, ano 15, n. 60, p. 39-62, abr./jun. 2015. p. 47.

${ }^{22}$ Lei $\mathrm{n}^{\circ}$ 8.987/95: “Art. 29. Incumbe ao poder concedente: (...) XI - incentivar a competitividade".

${ }^{23}$ Sobre esse efeito do regime concorrencial de prestação de serviço público, César Guimarães Pereira afirma que "nesse campo de liberdade é que, por excelência, encontra aplicação o CDC, suprindo o afastamento do Poder Concedente com a imposição ao concessionário de obrigações similares às que caracterizam as relações privadas". PEREIRA, César A. Guimarães. Usuários de serviços públicos: usuários, consumidores e os aspectos econômicos dos serviços públicos. São Paulo: Saraiva, 2006. p. 148-149.
}

Revista de Direito Brasileira | São Paulo, SP | v. 15 | n. 6 | p. 311 - 336 | set./dez. 2016 
Ainda que a abertura dos serviços públicos à livre concorrência possa contribuir para o aumento da produtividade e da eficiência da prestação, ${ }^{24}$ não se pode esquecer que essas atividades, sendo de titularidade exclusiva do Estado, continuam tendo como norte a satisfação do interesse público. Assim, deve-se atentar para que esses fatores não acabem por gerar um desequilíbrio na relação entre o público e o privado, que permeia todo o âmbito da prestação de serviços públicos concedidos aos particulares. ${ }^{25} \mathrm{Ou}$ seja, até mesmo a busca por uma prestação que atenda às necessidades específicas dos indivíduos deve ter como fim último a satisfação do interesse público. $^{26}$

O que se pode perceber nesse ponto é uma verdadeira mudança de foco do sistema de prestação dos serviços públicos. Parte-se de uma relação vertical, autoritária, entre Estado e cidadão - então encarado como mero "administrado" - voltada apenas à realização de objetivos macroeconômicos, para se chegar a um cenário de maior controle e regulação, ${ }^{27}$ no qual o objetivo maior é a prestação mais transparente dos serviços públicos, com melhores preços e condições adequadas, adaptando-se, na medida do possível, às necessidades pessoais de cada um. Nesse contexto, faz-se imperioso, cada vez mais, reconhecer a necessidade de "conciliação entre a proteção dos consumidores, de um lado, e as prerrogativas da Administração, de outro". ${ }^{28}$

O mais correto, portanto, parece ser a tomada de uma posição mais equilibrada entre as visões privatista e publicista. Afinal, se por um lado preocupar-se apenas em satisfazer as necessidades individuais não é suficiente para manter o bom funcionamento do sistema coletivo de prestação, por outro, o sentimento solidário por vezes é incapaz de resolver os diversos problemas advindos de um sistema de serviços públicos cada vez mais submetidos à concorrência de empresas privadas.

\section{O BENEFICIÁRIO DE SERVIÇO PÚBLICO PARA O DIREITO: USUÁRIO- CIDADÃO OU CONSUMIDOR-CLIENTE?}

Atualmente, percebe-se que as empresas (estatais ou privadas) prestadoras de serviço público consideram ter clientes - e não usuários - fenômeno que, inclusive, encontra respaldo doutrinário. ${ }^{29}$ Maria Paula Dallari Bucci, porém, em posição seguida por boa parte da doutrina, critica intensamente essa acepção, entendendo não existir entre o Estado e o cidadão usuário de

\footnotetext{
${ }^{24}$ Sobre a importância de se instituir meios mais eficientes de gestão de serviços públicos, ver: SACRISTÁN, Estela. Gestión eficiente y ética en la efectivización de los servicios públicos relativos a derechos sociales. Revista de Investigações Constitucionais, Curitiba, vol. 3, n. 1, p. 125-143, jan./abr. 2016.

${ }^{25}$ CHILLON, Sandie. De l'Usager au Consommateur... Op. Cit., p. 293-294.

${ }^{26}$ Sobre o assunto, Jorge Luis Salomoni lecionou que a tendência de especificação dos direitos fundamentais, que configura uma gradual determinação dos sujeitos titulares desses direitos, pressupõe que eles não estejam direcionados a um cidadão genérico, mas aos que se encontram, sejam por razões culturais, sociais ou econômicas, em uma situação de inferioridade, que deve ser compensada através da tutela administrativa de tais direitos fundamentais. Por tal motivo, "a análise das concessões de serviços públicos requer a introdução do sujeito usuário como fator determinante da interpretação de suas cláusulas". SALOMONI, Jorge Luis. Teoría General de los Servicios Públicos. Buenos Aires: Ed. Ad-Hoc, 1999. p. 396-397.

${ }^{27}$ A respeito da transformação do papel do Estado e a valorização da função regulatória, ver: DUARTE JÚNIOR, Ricardo César Ferreira. A legitimidade do Estado regulador brasileiro: uma análise democrática. A\&C - Revista de Direito Administrativo \& Constitucional, Belo Horizonte, ano 11, n. 43, p. 135-166, jan./mar. 2011; SILVA, Cristina Alves da; NELSON, Rocco Antonio Rangel Rosso. Agências reguladoras e evolução estatal - Uma análise temporal do papel do Estado no setor econômico. A\&C-Revista de Direito Administrativo \& Constitucional, Belo Horizonte, ano 13, n. 51, p. 49-73, jan./mar. 2013; MOURA, Emerson Affonso da Costa. O Estado gerencial, regulação econômica e serviços públicos - O papel das agências na promoção do desenvolvimento. A\&C-Revista de Direito Administrativo \& Constitucional, Belo Horizonte, ano 14, n. 57, p. 193-217, jul./set. 2014.

${ }^{28}$ LUCCA, Newton. Direito do Consumidor. São Paulo: Quartier Latin, 2003. p. 209-210.

${ }^{29}$ Essa posição é defendida, por exemplo, em: BRESSER-PEREIRA, Luiz Carlos. Reforma do Estado para a cidadania: a reforma gerencial brasileira na perspectiva internacional. São Paulo: Editora 34, 2002. p. 111-112.
}

Revista de Direito Brasileira | São Paulo, SP | v. 15 | n. 6 | p. 311 - 336 | set./dez. 2016 
serviços públicos a mesma contraposição de interesses que há entre o fornecedor privado e o seu cliente. ${ }^{30}$ Há de se concordar com essa última linha de pensamento, uma vez que uma das principais consequências da constitucionalização do Direito Administrativo foi a centralização da figura do cidadão como principal norte de toda a atividade administrativa. ${ }^{31} \mathrm{O}$ sentimento do cidadão como cliente da Administração pode distorcer os objetivos fundamentais de uma Administração Pública inclusiva, ${ }^{32}$ encarada como ente público gerido para o desenvolvimento da coletividade, que visa à concretização dos direitos fundamentais e à satisfação do interesse público, com o objetivo final de reduzir as desigualdades sociais, regionais e culturais existentes no país, para instituir uma sociedade livre, justa e solidária, nos termos do art. $3^{\circ}$ da Constituição da República.

Por existir a controvérsia, todavia, é interessante estudar o tema, a fim de que se possa compreender com melhor aptidão as diferenças entre as figuras do usuário e do consumidor. No atual ordenamento jurídico brasileiro, as concepções de usuário e consumidor são muito próximas e sujeitas a confusões, uma vez que ambos se caracterizam por serem destinatários de prestações (entrega de coisa, realização de serviço, fornecimento de produto, etc.) ofertadas por outras pessoas em uma rede de múltiplas relações econômicas massificadas. A distinção torna-se ainda mais dificultosa quando o usuário recebe a prestação a partir de uma relação jurídica padronizada, polarizada por um fornecedor privado (empresa concessionária), mediante o pagamento de uma tarifa. Frisa-se, com isso, que a árdua tarefa de distinguir usuário de consumidor não é mero capricho teórico ou tarefa de retórica jurídica, mas, sim, um importante instrumento para refletir os diferentes regimes jurídicos incidentes sobre essas figuras.

Contudo, os conceitos de consumidor e usuário partem de matrizes constitucionais diferentes. Para a Constituição, consumidor é uma figura típica das relações firmadas no âmbito da economia de mercado. Tanto é assim que lista, em seu art. 170, V, a defesa do consumidor como um dos princípios da ordem econômica.

É bem verdade, no entanto, que em determinadas passagens o próprio texto constitucional, se interpretado a partir de uma leitura apressada, fomenta a confusão entre esses dois conceitos. Um exemplo é o artigo 150 . No $\$ 3^{\circ}$ do referido dispositivo, a Constituição, ao tratar de imunidade tributária, refere-se a atividades econômicas do Estado em que se verifique "contraprestação ou pagamento de preços ou tarifas pelo usuário". Mais adiante, no $\$ 5^{\circ}$ do mesmo artigo, dispõe que "a lei determinará medidas para que os consumidores sejam esclarecidos acerca dos impostos que incidam sobre mercadorias e serviços". ${ }^{33}$ Cabe mencionar, ainda, a Emenda Constitucional $\mathrm{n}^{\text {o }}$ 29/2002, que insere na Lei Maior o art. 149-A, parágrafo único, o qual alude a "fatura de consumo de energia elétrica", um serviço dado como público pelo art. 21, XII, $b$ da Constituição.

Entretanto, após uma interpretação sistemática do texto constitucional, é evidente que a figura jurídica de usuário é algo completamente distinto da figura do consumidor. Como bem lembra César Guimarães Pereira, "além do art. $150, \S 3^{\circ}$, que insere o usuário na relação de

\footnotetext{
${ }^{30}$ BUCCI, Maria Paula Dallari. Direito administrativo e políticas públicas. São Paulo: Saraiva, 2002. p. 108-109.

31 RODRÍGUEZ-ARANA MUÑOZ, Jaime. El derecho fundamental a la buena Administración. Revista Eurolatinoamericana de Derecho Administrativo, Santa Fe, vol. 1, n. 2, p. 73-93, jul./dic. 2014. p. 74. No mesmo sentido: DELPIAZZO, Carlos E. Centralidad del administrado en el actual Derecho Administrativo: impactos del Estado Constitucional de Derecho. Revista de Investigações Constitucionais, Curitiba, vol. 1, n. 3, p. 7-32, set./dez. 2014.

${ }^{32}$ No sentido de uma Administração Pública inclusiva, Carlos Balbín ensina que "el Derecho Administrativo, en el marco del Estado Social y Democrático de Derecho, debe ser pensado como un derecho de inclusión y no solo como un derecho de prevención y eventualmente reparación de los abusos o arbitrariedades estatales." BALBÍN, Carlos F. Un Derecho Administrativo para la inclusión social. A\&C - Revista de Direito Administrativo \& Constitucional, Belo Horizonte, ano 14, n. 58, p. 33-59, out./dez. 2014. p. 53.

${ }_{33}$ Percebe-se aqui a atenção do constituinte a não se referir, nesse ponto, a serviços públicos, mas sim a serviços de forma genérica, compreendidos como uma atividade que é inerente à economia capitalista e globalizada contemporânea.
} 
prestação caracterizada como serviço público, o art. 175, II, da Constituição, trata dos 'direitos dos usuários' como devendo ser objeto da lei que regularia a concessão e a permissão de serviços públicos". ${ }^{34}$ Além disso, verifica-se ainda outras alusões a "usuário" no art. 37, §3: no inciso I enquanto beneficiário das prestações de serviço público (conferindo-lhe o sentido que pode confundi-lo com consumidor) e nos incisos II e III enquanto cidadão em geral.

A distinção dos sentidos atribuídos pela Constituição às figuras de usuário e consumidor é indiscutível ao se analisar, comparativamente, o art. 27 da Emenda Constitucional n 19/1998 que alude à edição de uma lei própria à defesa do usuário de serviços públicos - e o art. 48 dos Atos das Disposições Constitucionais Transitórias - que se refere ao Código de Defesa do Consumidor. Com isso, ao reportar-se à promoção de dois diplomas distintos (um para tratar dos usuários de serviços públicos e outro dos consumidores), deixa evidente a existência de dois regimes jurídicos diferenciados e específicos para cuidar de cada uma dessas questões.

Uma interessante característica do usuário que deve ser ressaltada - e que o diferencia do consumidor - é a de que ele não necessariamente é o destinatário final do serviço. O CDC define como consumidor "toda pessoa física ou jurídica que adquire ou utiliza produto ou serviço como destinatário final". Realizando, em face dessa norma, a interpretação finalista aprofundada referida por Cláudia Lima Marques, chega-se à conclusão de que o CDC exclui do âmbito de proteção do consumidor as grandes empresas que utilizam o produto ou serviço apenas como meio em sua produção e não como objetivo final. ${ }^{35}$ Por outro lado, é inegavelmente reconhecido como usuário todo aquele que, em algum momento da cadeia produtiva, utiliza-se do serviço público. Não faria sentido, já que não há qualquer prescrição legal nessa linha, restringir o conceito de usuário apenas ao indivíduo que recebe a energia elétrica em sua casa, excluindo a empresa que a utiliza para sua atividade comercial, por exemplo.

Mais um ponto que merece ser destacado, nessa mesma esteira, é quanto à onerosidade do produto/serviço. Por óbvio, para configurar-se como consumidor o indivíduo tem, além de outros requisitos, que despender recursos para obter seu produto, mediante uma contraprestação pecuniária. No entanto, aqui, mais uma vez, o usuário é regido por uma lógica diferenciada. Embora, na prática, a regra seja a de serviços públicos onerosos, nos quais o usuário é impelido à contraprestação, não se pode olvidar dos serviços públicos gratuitos, os quais, evidentemente, são fruídos por usuários sem necessidade de custeio direto, como é o exemplo da iluminação pública ou dos serviços beneficiados pelas chamadas "tarifas sociais", tal como ocorre com o abastecimento de água.

É de se ressaltar ainda que, diferentemente do consumidor, o usuário não é necessariamente vulnerável, sendo enquadradas na categoria de usuárias, por exemplo, todas as grandes empresas que usufruem do serviço público de energia elétrica em sua atividade, como já apontado acima. Assim sendo, "não é a vulnerabilidade que caracteriza o usuário, embora a consciência sobre a sua vulnerabilidade (na generalidade dos casos) possa introduzir um modo de pensar fundamental para a sua tutela adequada no âmbito do Direito Público" "36. É o caso, por exemplo, da vulnerabilidade técnica vivenciada pelos usuários frente aos prestadores e manifestada pela diferença de acesso a informações sobre a prestação do serviço. Diante disso justifica-se, independentemente do art. $6^{\circ}$, VIII, do $\mathrm{CDC},{ }^{37}$ a inversão do ônus da prova, inclusive no âmbito dos processos administrativos, impondo ao prestador o dever de provar a regularidade

\footnotetext{
${ }^{34}$ PEREIRA, César A. Guimarães. Usuários de serviços públicos: usuários, consumidores e os aspectos econômicos dos serviços públicos. São Paulo: Saraiva, 2006. p. 135.

${ }^{35}$ MARQUES, Cláudia Lima; BENJAMIN, Antônio Herman V; MIRAGEM, Bruno. Comentários ao Código de Defesa do Consumidor. 2. ed. rev., atual. e ampl. São Paulo: Editora Revista dos Tribunais, 2006. p. 83-85.

${ }^{36}$ PEREIRA, César A. Guimarães. Usuários de serviços públicos... Op. Cit. p. 198.

${ }^{37}$ Código de Defesa do Consumidor: "Art. $6^{\circ}$. São direitos básicos do consumidor: (...) VIII - a facilitação da defesa de seus direitos, inclusive com a inversão do ônus da prova, a seu favor, no processo civil, quando, a critério do juiz, for verossímil a alegação ou quando for ele hipossuficiente, segundo as regras ordinárias de experiências".
}

Revista de Direito Brasileira | São Paulo, SP | v. 15 | n. 6 | p. 311 - 336 | set./dez. 2016 
de sua conduta. Esta disposição é extraível do direito dos usuários previsto no $\operatorname{art.} 7^{\circ}$, II, da Lei $\mathrm{n}^{\circ}$ $8.987 / 95^{38}$

Outro relevante traço da distinção entre usuário e consumidor é levantado por Cristiane Derani. Para ela, consumidor é aquele que vai ao mercado (em sentido amplo) buscar os produtos e bens que lhe são ofertados, com base nos preços livremente estipulados pela iniciativa privada. Enxerga aí, portanto, uma grande liberdade de escolha. O usuário, por sua vez, muitas vezes não possui a liberdade de escolher o "produto" que mais lhe interessar, baseado na oferta e no preço. Na definição da autora, "usuário é aquele que constantemente faz uso de uma quantidade de determinada mercadoria para sua existência social, uso que independe de preço, da oferta e da escassez do mercado". ${ }^{39}$ Essa afirmação torna-se indiscutível quando se analisa, por exemplo, o caso dos serviços públicos de coleta e tratamento de esgoto, dos quais o usuário não apenas não possui liberdade de escolher o prestador de quem receberá o serviço, como sequer pode escolher não receber o serviço. Trata-se de um serviço público obrigatório, que, como tal, deve ser indispensavelmente fruído, sob pena de se causar danos a toda a coletividade.

Com esses exemplos, já se tornam evidentes os diversos aspectos distintivos entre usuário e consumidor. Ainda que haja uma "necessidade de maior proteção aos usuários de serviços públicos, o que implica, inclusive, ampliação de seu conceito", ${ }^{40}$ deve-se saber que representam duas figuras distintas, às quais se aplicam diferentes regimes jurídicos.

É inegável que, em determinadas situações, como será tratado adiante, o usuário de serviço público se assemelhará muito a um consumidor, pois sua relação com o prestador do serviço será também muito semelhante a uma relação consumerista. No entanto, o usuário de serviço público ainda é uma figura típica do Direito Administrativo, diferenciando-se, em maior ou menor grau, da figura do consumidor. Sendo assim, não se pode admitir a equiparação dos sentidos de usuário-cidadão e de consumidor-cliente, "na medida em que essa concepção contribui para enfraquecer o sentimento da Administração como coisa pública, gerida pelos integrantes da coletividade e para a realização de seus interesses". ${ }^{41}$ Apesar de tudo isso, como será analisado na sequência, uma diferença (ainda que relevante como essa) na natureza do conceito de usuário e de consumidor não leva, direta e necessariamente, à conclusão de que o CDC não pode servir como diploma normativo protetor dos usuários de serviços públicos em determinadas situações.

\section{A IMPROPRIEDADE DE UMA DIVISÃO ESTANQUE ENTRE 0 DIREITO PÚBLICO E O DIREITO PRIVADO E O REGIME JURÍDICO APLICÁVEL AOS USUÁRIOS DE SERVIÇOS PÚBLICOS: O DIREITO COMO UM TODO INDIVISÍVEL}

Existem diversas teorias que buscam explicar o regime jurídico aplicável aos usuários de serviços públicos. Pode-se, sistematicamente, separá-las em três grandes correntes: (i) privatistas; (ii) publicistas; (iii) mistas.

(i) As correntes privatistas baseiam-se, principalmente, nos serviços públicos chamados de industriais ou comerciais, nos quais o usuário paga por aquilo que consome. Os maiores

\footnotetext{
${ }^{38}$ Lei $\mathrm{n}^{\circ}$ 8.987/95: “Art. $7^{\circ}$. Sem prejuízo do disposto na Lei $\mathrm{n}^{\circ}$ 8.078, de 11 de setembro de 1990, são direitos e obrigações dos usuários: (...) II - receber do poder concedente e da concessionária informações para a defesa de interesses individuais ou coletivos".

${ }^{39}$ DERANI, Cristiane. Privatização e serviços públicos: as ações do Estado na produção econômica. São Paulo: Max Limonad, 2002. p. 76-77.

${ }^{40}$ CUÉLLAR, Leila. Serviço de abastecimento de água e a suspensão do fornecimento. Revista de Direito Público da Economia - RDPE, Belo Horizonte, ano. 1, n. 3, p. 131-159, jul/set. 2003. p. 142.

${ }^{41}$ BUCCI, Maria Paula Dallari. Direito administrativo e políticas públicas... Op. Cit. p. 115.
} 
exemplos aqui são os serviços públicos delegados à iniciativa privada. Para essas teorias, não é por haver normas de Direito Público incidindo sobre as relações contratuais firmadas entre as empresas concessionárias e os usuários que estas passam a ser relações de Direito Público. É de se frisar, porém, que não há uma "teoria privatista pura quanto à caracterização jurídica dos usuários dos serviços públicos, já que mesmo os que defendem a natureza privada do vínculo admitem o forte influxo de normas de Direito Público concernentes ao serviço". ${ }^{2}$

(ii) As teorias publicistas, por sua vez, defendem que é o Direito Público que rege as relações entre os cidadãos e o prestador do serviço público, ainda que se tratando de um serviço industrial/comercial. Segundo os defensores dessa linha, tais relações são de Direito Público pois tratam de uma tarefa própria (embora delegável a particulares) da Administração Pública. Além disso, todas as relações, ainda que as vivenciadas entre particulares e empresas delegadas, fundam-se, em última análise, em um direito de natureza jurídica pública: o direito fundamental ao serviço público adequado. ${ }^{43}$ Para aqueles se filiam a essa corrente, soma-se a isso, ainda, o fato de que, em sua visão, não há liberdade significativa para o usuário e o concessionário discutirem os termos do contrato que celebrarão. Afinal, as principais cláusulas do contrato já estarão previamente estabelecidas estatutariamente, sejam em normas legais ou regulamentares, previstas em atos administrativos ou no próprio contrato de concessão - que, inclusive, pode ser alterado unilateralmente pela Administração Pública. ${ }^{44}$

A pequena autonomia contratual de criar cláusulas não previstas em lei - permitida aos particulares pela Administração - não intimida os defensores dessa corrente. Para eles, apesar desse espaço de autonomia, a prerrogativa de que goza a Administração Pública de alteração unilateral de seus contratos faz com que as exigências dos particulares não sejam, na prática, de cumprimento cogente. Por tal motivo, sempre estaria assegurado o campo de incidência das normas de Direito Público.

(iii) Para os defensores das teorias mistas, há, nas relações de serviço público, espaço de incidência tanto de normas de Direito Privado, como de Direito Público. Apesar de a relação que o usuário mantém com a empresa prestadora do serviço ser contratual, o fato de a busca pela satisfação do interesse público ser o fator de legitimação desses serviços justifica que seu regime jurídico seja estabelecido pelo Estado. Portanto, ainda que se trate de uma relação contratual, com determinada autonomia de vontade das partes para estabelecer novas cláusulas, deve-se entender que, diferentemente das contratações privadas, a prestação de serviços públicos se encontra vinculada a uma missão maior, de forte dimensão política, ${ }^{45}$ que, no caso brasileiro, pode ser entendida como a concretização dos objetivos fundamentais da República.

Para Fernando Garrido Falla, deve-se ter em mente, antes de mais nada, que a antiga noção de serviço público submetido às exorbitantes normas do Direito Administrativo clássico está ultrapassada. ${ }^{46}$ Atualmente, nos serviços públicos cuja prestação é concedida à iniciativa privada, a Administração Pública tem o dever de regulamentar, pelos meios jurídicos e administrativos de que dispõe, o uso e funcionamento do serviço pelo usuário (além do dever de

\footnotetext{
${ }^{42}$ ARAGÃO, Alexandre Santos de. Direito dos serviços públicos. 3. ed. Rio de Janeiro: Forense, 2013. p. 491.

${ }^{43}$ Para uma análise aprofundada do conceito de serviço público adequado, cf. HACHEM, Daniel Wunder. Direito fundamental ao serviço público adequado e capacidade econômica do cidadão: repensando a universalidade do acesso à luz da igualdade material. A\&C-Revista de Direito Administrativo \& Constitucional. Belo Horizonte, ano 14, n. 55, p. 123-158, jan./mar. 2014.

${ }^{44}$ Nesse sentido: FRAGA, Gabino. Derecho Administrativo. 8. ed. Cidade do México: Ed. Porruá, 1960. p. 262.

45 AMAR, Jacques. De l'Usager au Consomatteur de Service Public... Op. Cit. p. 29-30.

46 Sobre o tema específico da superação do regime jurídico-administrativo baseado unicamente nas normas exorbitantes e nas prerrogativas da administração Pública, ver: CORVALÁN, Juan Gustavo. Transformações do "regime de Direito Administrativo" - A propósito do regime exorbitante e das prerrogativas da Administração Pública. A\&C - Revista de Direito Administrativo \& Constitucional, Belo Horizonte, ano 13, n. 51, p. 49-73, jan./mar. 2013.
} 
garantir sua prestação de modo adequado). Essa regulamentação, segundo o administrativista espanhol, será tanto mais presente e intensa quanto mais o serviço possua características "administrativas" - e não industriais ou comerciais - e seja gerido diretamente pela Administração. Assim, é possível dizer que o regime jurídico incidente sobre usuários de serviços públicos concedidos é, ao mesmo tempo, parte "estatutário" e parte contratual. ${ }^{47}$

Concorda-se, aqui, com essa última corrente por se entender que o Direito dos Serviços Públicos no Brasil encontra-se, atualmente, em um caráter misto (contratual-regulamentar). De um lado tem clara natureza pública, vez que está fortemente submetido às regulamentações administrativas - estando, nesse aspecto, sob vigilância e proteção da Administração Pública. Por outro, porém, essa situação regulamentar só é praticada após a celebração de um contrato entre dois particulares (cidadão e concessionário), que será válido e eficaz em tudo aquilo que não contrariar as normas regulamentares. A relação de serviço público, portanto, é tripartite, entre Administração, concessionário e usuário, sendo mais correto se falar, nessa lógica, em relações (no plural) de serviço público: (i) entre a Administração e o concessionário; (ii) entre o concessionário e o usuário e (iii) entre a Administração e o usuário.

Essa posição mista, de um sistema contratual e regulamentar, ora mais próximo do Direito Público e ora mais próximo do Direito Privado, é deduzível também a partir do Direito positivo brasileiro.

A Constituição Federal, em seu art. 175, parágrafo único, II, determinou que a disciplina legal dos serviços públicos disporá sobre a fixação dos direitos dos usuários. Diante disso, a Lei $\mathrm{n}^{\circ}$ 8.987/95, que dispõe sobre o regime de concessão e permissão da prestação de serviços públicos, prescreveu em seu art. $7^{\circ}$ os direitos e obrigações dos usuários, deixando expresso que aquele rol não excluía ou prejudicava o constante no Código de Defesa do Consumidor.

Além disso, há exemplos de legislação sobre regulação de serviço público que faz remissão à defesa do consumidor. É o caso da Lei $\mathrm{n}^{\circ}$ 9.478/97, que dispõe sobre a política energética nacional e que, em seu art. $1^{\circ}$, III, estabelece como um dos objetivos desta a proteção dos "interesses do consumidor quanto a preço, qualidade e oferta dos produtos". Outro exemplo é a Lei $n^{\circ}$ 9.472/97 (Lei das Telecomunicações), que, em seu art. $5^{\circ}$, ao discriminar diversos princípios a serem observados nas relações econômicas do setor de telecomunicações, elenca entre eles, expressamente, o da defesa do consumidor.

O próprio Código de Defesa do Consumidor possui diversos dispositivos - que serão analisados adiante - que remetem expressamente a serviços públicos e a usuários, demonstrando, mais uma vez, que não se pode defender sua (in)aplicabilidade de modo absoluto.

Assim, deve-se deixar registrada a impropriedade de se afirmar uma separação estanque entre o Direito Público e o Privado nos dias atuais - situação que é, para muitos, o principal motivo de discussão quando se está analisando a possibilidade de aplicação do CDC às relações de serviços públicos. Essa divisão é antiga, fruto do desenvolvimento do Estado Liberal. Com a queda do absolutismo monárquico no final do século XVIII e início do século XIX, o Direito ocidental europeu passou a dividir claramente o que seria o âmbito de atuação do Estado (Direito Público) e o dos indivíduos (Direito Privado). A desconfiança em relação ao Estado nesse

\footnotetext{
${ }^{47}$ FALLA, Fernando Garrido. Tratado de Derecho Administrativo. 9. ed. Madrid: Ed. Tecnos, 1985. p. 382. Essa posição é seguida por diversos outros autores, tanto em âmbito nacional, como estrangeiro. É o caso, por exemplo, de Alexandre Santos de Aragão: "a prestação de serviços públicos, especificamente quando delegados à iniciativa privada, é regida em parte por um estatuto de regulamentação pública. Mas só se entra sob a incidência desse estatuto mediante a celebração de um contrato de prestação de serviço entre dois particulares (usuário e concessionário), que, como tal, é de natureza civil em todos os aspectos que não contrariem a situação estatutária" (ARAGÃO, Alexandre Santos de. Serviços Públicos... Op. Cit., p. 493). Em sentido semelhante, no direito comparado: CASSAGNE, Juan Carlos. La Intervención Administrativa. 2. ed. Buenos Aires: Abeledo-Perrot, 1994. p. 55-56.
} 
período era tamanha que a função do Direito Público não era outra senão a de garantir a existência do espaço de liberdade dos indivíduos. ${ }^{48}$

No Brasil, principalmente após a promulgação da Constituição Federal de 1988, essa concepção divisionista caiu por terra. Devido ao fenômeno da constitucionalização do Direito Privado, torna-se mais difícil - senão impossível - identificar institutos jurídicos que não sofram reflexos dos princípios gerais do Direito Público. Como bem assinala Romeu Felipe Bacellar Filho, "a Constituição abala as estruturas do Direito Privado", 49 penetrando em toda a malha do ordenamento jurídico e contribuindo significativamente para a derrocada da fronteira entre o Público e o Privado.

A concepção unitária de sistema jurídico ganha ainda mais evidência no paradigma do Estado Social. Afinal, com a "transferência para o Estado de novas funções de inclusão e compensação, a delimitação entre Direito Público e Privado deixa de ser ontológica para assumir uma mera feição didático-pedagógica". ${ }^{50}$ Nesse mesmo sentido, Pietro Perlingieri afirma que "se em uma sociedade onde é precisa a distinção entre liberdade do particular e autoridade do Estado, é possível distinguir a esfera do interesse dos particulares daquela do interesse público, em uma sociedade como a atual, torna-se difícil individuar um interesse particular que seja completamente autônomo, independente, isolado do interesse dito público". 51

Um dos problemas concretos em que mais se discute a aplicabilidade do CDC às relações de serviço público é a questão da suspensão do fornecimento do serviço por falta de pagamento do usuário. ${ }^{52}$ E esse é exatamente um dos mais claros exemplos dessa confluência entre o Direito Público e o Privado: analisa-se, nessas situações, se o inadimplemento de uma obrigação por parte de um usuário pode fazer com que uma empresa privada concessionária de serviço público interrompa a prestação desse serviço para não contrair prejuízos. A concorrência entre institutos tidos como típicos do Direito Público ou do Direito Privado nesses casos é evidente, o que demonstra manifestamente o fato de que o Direito é um todo indivisível, cuja separação em disciplinas se dá apenas por razões didáticas. Desse modo, "para atender aos seus elevados misteres, a Administração Pública deve valer-se do ordenamento jurídico como um todo, buscando, mediante uma interpretação conforme a Constituição, melhor atender seus desígnios". 53

Por esse motivo, deve ser afastada a noção de que o Código de Direito do Consumidor é um diploma legislativo do Direito Privado e que, apenas por tal motivo, não se aplicaria de modo algum às relações de serviço público. Ainda que essa seja a solução menos trabalhosa, não é, definitivamente, a mais correta. O caminho a ser seguido, desse modo, é o do estudo

\footnotetext{
${ }^{48}$ ARAÚJO PINTO, Cristiano Paixão. Arqueologia de uma distinção: o público e o privado na experiência histórica do direito: In: PEREIRA, Cláudia Fernanda de Oliveira (Org.). O novo direito administrativo brasileiro: o Estado, as agências e o terceiro setor. Belo Horizonte: Fórum, 2003. p. 37.

${ }^{49}$ BACELLAR FILHO, Romeu Felipe. Direito administrativo e o novo Código Civil. Belo Horizonte: Fórum, 2007. p. 81.

${ }_{50}$ ARAÚJO PINTO, Cristiano Paixão. Arqueologia de uma distinção... Op. Cit. p. 36.

${ }^{51}$ PERLINGIERI, Pietro. Perfis do direito civil: uma introdução ao direito civil constitucional. 2. ed. Rio de Janeiro: Renovar, 2002. p. 53.

52 Sobre o tema, ver: FARIA, Luzardo. A suspensão do fornecimento de serviço público essencial por inadimplemento do usuário: o interesse público entre eficiência e dignidade. In: BLANCHET, Luiz Alberto; HACHEM, Daniel Wunder; SANTANO, Ana Cláudia (Coords.). Eficiência e Ética na Administração Pública. Curitiba: Editora Íthala, 2015. p. 109-134; LEAL, Rogério Gesta. O problema de prestação de serviço público essencial enquanto Direito Social Fundamental e sua contraprestação em face da incapacidade financeira do usuário. In: LEAL, Rogério Gesta. Condições e possibilidades eficaciais dos direitos fundamentais sociais: os desafios do Poder Judiciário no Brasil. Porto Alegre: Livraria do Advogado, 2009. p. 135-149; DOMINGUEZ, Guilherme Diniz de Figueiredo. A interrupção no fornecimento dos serviços públicos de energia elétrica e água, por inadimplência dos usuários, à luz da jurisprudência dos tribunais superiores (STJ e STF). Revista de Direito Público da Economia, Belo Horizonte, ano 6, n. 24, p. 219-236, out./dez. 2008.

${ }^{53}$ BACELLAR FILHO, Romeu Felipe. A Administração Pública entre o Direito Público e o Direito Privado. Revista de Direito Civil Contemporâneo. São Paulo, v. 3, n. 2, p. 31-53, abr./jun. 2015. p. 33.
}

Revista de Direito Brasileira | São Paulo, SP | v. 15 | n. 6 | p. 311 - 336 | set./dez. 2016 
contextualizado e sistematizado das normas dispostas no CDC, considerando-se, sempre, sua função e sua natureza jurídica.

\section{AS POSSÍVEIS SITUAÇõES E MÉTODOS DE APLICAÇÃO DO CÓDIGO DE DEFESA DO CONSUMIDOR ÀS RELAÇÕES DE SERVIÇO PÚBLICO: A NECESSIDADE DE FILTRAGEM CONSTITUCIONAL}

O CDC, no seu art. $2^{\circ}$, caput, define consumidor como "toda pessoa física ou jurídica que adquire ou utiliza produto ou serviço como destinatário final” e, no seu art. $3^{\circ}$, caput, trata de classificar fornecedor como "toda pessoa física ou jurídica, pública ou privada, nacional ou estrangeira, bem como os entes despersonalizados que desenvolvem atividades de produção, montagem, criação, construção, transformação, importação, exportação, distribuição ou comercialização de produtos ou prestação de serviços". No art. $6^{\circ}, \mathrm{X}$ assegura, como direito básico do consumidor, "a adequada e eficaz prestação dos serviços públicos em geral". Ainda, no art. 22, caput, determina que "os órgãos públicos, por si ou suas empresas, concessionárias, permissionárias ou sob qualquer outra forma de empreendimento, são obrigados a fornecer serviços adequados, eficientes, seguros e, quanto aos essenciais, contínuos". Há diversos outros dispositivos do CDC em que se pode encontrar o termo "serviço" como foco da norma. Ao que tudo indica, então, esta lei parece ter sido produzida para se aplicar também às relações de serviços públicos.

Com isso, deve-se deixar claro desde o início que, embora o CDC não se refira expressamente a "usuários de serviços públicos", é nítida a sua aplicabilidade às pessoas que se encontram nessa posição. Entende-se, nesse sentido, que "o CDC ignorou o conceito de usuário não porque o equiparou a consumidor, mas porque, em relação ao serviço público, optou por uma regulação baseada na prestação, não no usuário ou no fornecedor". 54

Sendo assim, é inegável que há determinados dispositivos do CDC que claramente tratam de serviços públicos e que, como tais, devem ser aplicados a esse âmbito sem maiores discussões. É o caso, por exemplo, do citado art. 22, que indubitavelmente deve ser aplicado a todos os casos envolvendo serviços públicos. Por isso, aplica-se indiscriminadamente a responsabilização, determinada pelo CDC, do Poder Público pela prestação de serviço inseguro, inadequado, ineficiente ou descontínuo. ${ }^{55}$

Boa parte da doutrina reage a esse contexto, afirmando - corretamente, diga-se de passagem - a impossibilidade de se aplicar o CDC indiscriminadamente. De fato, é papel da doutrina (e também da jurisprudência) identificar em quais casos uma remissão ao CDC será devida e legítima e em quais situações isso não será adequado. Afinal, como já se disse, se por um lado não se pode negar a incidência das normas consumeristas, por outro, não se pode querer aplicá-las sem qualquer parâmetro.

Dinorá Adelaide Musetti Grotti, por exemplo, defendendo uma posição bastante difundida, afirma que "é a exigência de remuneração individualizada pela prestação de determinado serviço público que vai determinar a incidência de proteção jurídica regulada e estabelecida pelo CDC". ${ }^{56}$ Nessa lógica, por consequência, os serviços públicos prestados gratuitamente e aqueles uti universi não seriam abrangidos pelo CDC. Essa posição é seguida por diversos outros autores, como Regina Helena Costa, ${ }^{57}$ Cláudia Lima Marques, ${ }^{58}$ Adriano Perácio

\footnotetext{
${ }^{54}$ PEREIRA, César A. Guimarães. Usuários de serviços públicos... Op. Cit. p. 142.

${ }_{55}$ ALMEIDA, João Batista de. A proteção jurídica do consumidor. 4. ed. São Paulo: Saraiva, 2003. p. 99-101.

${ }^{56}$ GROTTI, Dinorá Adelaide Musetti. O serviço público e a Constituição brasileira de 1988... Op. Cit. p. 347.

${ }^{57}$ COSTA, Regina Helena. A tributação e o consumidor. Revista do Instituto de Pesquisas e Estudos - Divisão Jurídica, Bauru, ano 32, n. 17, p. 217-227, abr./jun. 1997. p. 224-225.

${ }^{58}$ MARQUES, Cláudia Lima. Contratos no Código de Defesa do Consumidor... Op. Cit. p. 486, 493. Revista de Direito Brasileira | São Paulo, SP | v. 15 | n. 6 | p. 311 - 336 | set./dez. 2016
} 
de Paula, ${ }^{59}$ e Adalberto Pasqualotto ${ }^{60}$. A jurisprudência brasileira também tende a acatar esse posicionamento. O Superior Tribunal de Justiça possui entendimento pacífico nesse sentido. ${ }^{61}$ Outro interessante indicativo de solução para essa problemática é o desenvolvido por César Guimarães Pereira. Em suas lições, a aplicabilidade do CDC se dá principalmente nos campos em que há algum tipo de liberdade de escolha dos termos contratuais firmados entre fornecedor e usuário, "o que não prejudica a aplicação generalizada das normas do CDC que não configurem Direito do Consumidor, mas Direito Administrativo (como a do art. 22 do CDC), e da disciplina processual de defesa do consumidor, integralmente aplicável ao usuário". ${ }^{2}$ Marçal Justen Filho defende posição semelhante, afirmando que "a disciplina do Direito do Consumidor apenas se aplicará na omissão do Direito Administrativo e na medida em que não haja incompatibilidade com os princípios fundamentais norteadores do serviço público". 63

Essas definições podem ser muito interessantes para se tratar da conceituação de consumidor. De fato, os usuários de serviços públicos uti singuli remunerados por meio de tarifas se assemelham, em muitas situações, à figura do consumidor. Veja-se o exemplo das telecomunicações. Esse setor é tão liberalizado, contando com forte concorrência e com remuneração individual, que a maior parte da população brasileira certamente deve pensar tratar-se de um serviço comercial comum - e não de um serviço público delegado. As relações firmadas entre o usuário do serviço de telecomunicação e a empresa possuem um tom claramente consumerista.

Por outro lado, nos serviços públicos gratuitos e uti universi - como a educação e a saúde pública, por exemplo - não se costuma cogitar tratar-se de uma relação de consumo. Parece ser de grande aceitação a ideia de que o estudante de uma escola pública ou um paciente do Sistema Único de Saúde não são consumidores ou clientes do Estado. E nessas situações se refuta completamente a aplicabilidade do CDC.

Respeitando todas as louváveis posições citadas acima, aqui se defende que a natureza consumerista da relação não é a questão que deve guiar o problema da aplicabilidade do CDC. Ou seja, o CDC pode ser aplicado às situações que envolvem prestação de serviços públicos independentemente da existência de uma relação consumerista, pois a aplicação de suas normas não se limita a essas relações.

Em primeiro lugar, isso se deve ao fato acima analisado de que, atualmente, não se pode mais sustentar uma divisão estanque entre o Direito Público e o Direito Privado. Não é porque o CDC é uma lei que foi produzida para tratar principalmente de casos oriundos de relações privadas que sua aplicabilidade às relações em que haja algum tipo de participação do Poder Público será rechaçada, notadamente quando essa aplicabilidade está ligada à proteção jurídica de direitos fundamentais dos usuários de serviços públicos (cidadãos, muitas vezes, vulneráveis jurídica e economicamente).

Em segundo lugar, a tese de que o CDC só poderia ser aplicado aos serviços públicos remunerados individualmente por tarifa, por exemplo, abriria margem para legitimar a falta de proteção jurídica dos usuários de outros serviços públicos. Afinal, desde 1998 o país espera pela produção de uma lei específica para a proteção dos usuários de serviços públicos. Embora haja proposições legislativas sobre isso tramitando no Congresso Nacional, já se passaram mais de 17 anos e a lei ainda não foi aprovada. O Conselho Federal da Ordem dos Advogados do Brasil até já ingressou com uma Ação de Inconstitucionalidade por Omissão para que o Supremo Tribunal Federal tente retirar o Congresso Nacional desta mora. De concreto, porém, ainda não houve qualquer resultado. ${ }^{64}$

${ }^{59}$ PAULA, Adriano Perácio de. O Código do Consumidor e o princípio da continuidade dos serviços públicos comerciais e industriais. Revista de Informação Legislativa, Brasília, ano 30, n. 118, p. 403-414, abr./jun. 1993. p. 405, 407-408.

${ }^{60}$ PASQUALOTTO, Adalberto. Os serviços públicos no Código de Defesa do Consumidor. Revista Direito do Consumidor, São Paulo, ano. 1, n. 1, p. 130-148. jan./mar. 1992. p. 134-135.

${ }^{61}$ É o que se vê, por exemplo, nas ações que envolvem a aplicação do CDC em casos de serviços públicos sobre manutenção de rodovias (REsp 467.883/RJ), cobrança de pedágio (REsp 772.843/RJ), distribuição de água potável (REsp 263.229/SP), coleta e tratamento de esgoto (AgRg no AI 1.398.696/RJ), correios (REsp 527.137/PR), telecomunicações (REsp 976.836/RS), etc.

${ }_{62}^{62}$ PEREIRA, César A. Guimarães. Usuários de serviços públicos... Op. Cit. p. 162.

${ }^{63}$ JUSTEN FILHO, Marçal. Teoria geral das concessões de serviço público. São Paulo: Dialética, 2003. p. 560.

${ }^{64}$ Logo no ano seguinte à edição da EC no $19 / 98$, o Senador Lucio Alcântara (PSDB-CE) apresentou um Projeto de Lei $\left(n^{\circ} 439 / 99\right)$ que "dispõe sobre a proteção e defesa do usuário dos serviços públicos prestados pela administração direta, indireta e delegada da União." Em junho de 2002, o PLS foi aprovado pelo Plenário do Senado Federal e enviado para apreciação da Câmara dos Deputados. Após mais de 13 anos de tramitação nesta casa, em 15/10/2015 foi aprovado pelo Plenário da Câmara um substitutivo àquele projeto de lei (de ${ }^{\circ}$ 6.953/02). Em seguida, o PLC substitutivo foi enviado para apreciação do Senado Federal, onde, desde 13/11/2015, aguarda apreciação da Comissão de Constituição, Justiça e Cidadania. Diante de tamanha mora legislativa, em junho de 2013 o Conselho Federal da Ordem dos Advogados do Brasil ajuizou uma Ação Direta de Inconstitucionalidade por Omissão (n ${ }^{\circ}$ 24) perante o Supremo Tribunal Federal. Nesses autos, em 01/07/2013, o Min. Rel. Dias Toffoli deferiu em parte a medida cautelar requerida pela OAB, determinando "aos Presidentes da Câmara dos Deputados e do Senado Federal,

Revista de Direito Brasileira | São Paulo, SP | v. 15 | n. 6 | p. 311 - 336 | set./dez. 2016 
Como dito acima, é claro que o estudante de uma escola pública não é um consumidor. Ele, aliás, é o mais característico exemplo de um usuário de serviço público. No entanto, caso se negue a aplicação do CDC a casos em que o estudante esteja envolvido com a escola em que frequenta, ele ficará sem um diploma normativo para lhe proteger, já que não existe legislação específica. Nesse sentido, negar a aplicabilidade do CDC simplesmente porque o usuário não paga uma tarifa individual para usufruir o serviço é marginalizar esses cidadãos do âmbito da proteção jurídica (que o Estado deve a todos, sem qualquer distinção).

O mesmo problema ocorre quando se segue a corrente segundo a qual o CDC só seria aplicável na omissão do Direito Administrativo, nos "espaços de liberdade" deixados pela Administração para livre negociação entre o usuário e o prestador. Mais uma vez, pode-se afirmar que nesses espaços encontram-se traços mais fortes de uma relação consumerista. A lógica desse método, na prática, esbarra em situações paradoxais, que podem gerar uma proteção maior do usuário de serviços prestados por concessionárias privadas do que aquela conferida aos que usufruem de serviços executados diretamente pelo Poder Público.

Tome-se o fato de que, inegavelmente, existem maiores "espaços de liberdade" nos setores em que a prestação do serviço público é delegada à iniciativa privada. Afinal, nessas situações há uma leve retirada da Administração Pública. Partindo-se do pressuposto de que a delegação de serviços públicos aumenta o espaço de liberdade para negociação existente entre usuário e prestador - no qual, por excelência, aplica-se o CDC - inadmitir a aplicabilidade de determinadas disposições dessa lei a usuários que se encontrem em outras situações, teria por consequência o privilégio dos usuários atendidos por prestadoras privadas em detrimento daqueles que têm o Estado como prestador (já que nessa situação não haveria tantos "espaços de liberdade").

Ou seja, na relação de serviço púbico na qual o prestador fosse alguma empresa privada, o usuário teria um diploma legislativo para protegê-lo; no caso de prestação direta por alguma entidade estatal, porém, ele estaria desprotegido. É evidente que essa lógica não merece prosperar. Não se pode admitir que, por uma inércia do Poder Legislativo, os usuários de serviços públicos prestados diretamente pelo Estado estejam menos protegidos juridicamente do que aqueles de serviços cuja prestação o Estado tenha delegado a empresas privadas.

A bem da verdade, o Código de Defesa do Consumidor foi editado com um objetivo bastante parecido com o que norteia muitos princípios do regime jurídico-administrativo: $a$ especial tutela dos direitos do cidadão que, frente a um ente prestador de serviços, vê-se em uma situação de hipossuficiência. Em razão disso, por admitir (i) que existem normas típicas de Direito Administrativo dispostas ao longo do CDC e (ii) que a essência ou o espírito do CDC é muito semelhante ao que se espera de uma legislação de proteção aos usuários de serviços públicos, entende-se na falta desta pela aplicabilidade daquele, desde que as normas consumeristas postas em questão passem pela filtragem constitucional responsável pelo delineamento do regime jurídico-administrativo.

Filtragem constitucional é o fenômeno que determina que toda a legislação infraconstitucional, para ser válida e eficaz, deve ser interpretada e aplicada em conformidade com a Constituição. Para isso, baseia-se em premissas como "a defesa da força normativa da Constituição, a necessidade de uma dogmática constitucional principialista, a retomada da legitimidade e vinculatividade dos princípios, o desenvolvimento de novos mecanismos de concretização constitucional, o compromisso ético dos operadores do Direito com a Lei Fundamental e a dimensão ética e antropológica da própria Constituição, a constitucionalização

bem assim à Presidência da República, que adotem providências para que a análise do Projeto de Lei $\mathrm{n}^{\circ} 6.953 / 2002$ (Substitutivo do PL n 674/1999) e sua conversão em lei ocorram, no prazo máximo, de 120 (cento e vinte) dias". Embora a decisão não tenha sido rigorosamente cumprida nesses termos, foi suficiente para que a Câmara dos Deputados conferisse ao PLC tramitação em regime de urgência. 
do direito infraconstitucional, bem como o caráter emancipatório e transformador do Direito como um todo". 65

Segundo Paulo Ricardo Schier, ${ }^{66}$ esse conceito se desenvolveu no Brasil em um momento no qual ainda se batalhava pela concretização da força normativa da Constituição Federal de 1988. Por um bom tempo após sua promulgação, grandes setores da sociedade eram receosos quanto à efetividade das normas constitucionais, por não se identificarem condições políticas, sociais e econômicas para sua plena realização. Atualmente, esse problema parece já ter sido superado. Ninguém mais nega que a Constituição Federal ostenta absoluta eficácia jurídica. No entanto, em que pese o convencimento geral acerca da força jurídico-normativa das normas constitucionais no plano teórico, ainda é necessário que se continue a busca pela sua realização prática. É essa, pois, a principal função da chamada filtragem constitucional: possibilitar que apenas normas compatíveis com a ordem constitucional vigente possam ser aplicadas na prática.

Aplicando-se a teoria da filtragem constitucional ao caso ora analisado, chega-se à conclusão (partindo das premissas acima expostas) de que só poderão ser aplicáveis às relações de serviços públicos as normas do Código de Defesa do Consumidor que passarem pelo filtro das normas que delimitam o regime jurídico-constitucional dos serviços públicos no Brasil. Como já salientado, o CDC não precisa ser aplicado apenas nos casos em que se estiver diante de uma relação de consumo. Todavia, as situações que perpassem esse cenário são situações extraordinárias, nas quais deve-se ter o maior cuidado metodológico, para que a aplicação das normas do CDC possa se dar em conformidade com a Constituição. Não se pode abruptamente transplantar todas as normativas do $\mathrm{CDC}$ aos casos em que se estiver analisando relações de serviços públicos.

Assim, o "empréstimo" das normas do CDC para solucionar conflitos gerados a partir de relações de serviços públicos só será possível se a aplicação dessa norma for compatível com os ditames constitucionais que delimitam aquela situação. No próximo tópico serão analisados alguns casos nos quais a aplicação de determinadas normas do CDC não passa pelo filtro constitucional. Nesse momento, porém, cabe destacar a outra face dessa moeda: as situações em que o CDC é perfeitamente aplicável às relações de serviços públicos, sendo suas normas compatíveis com a noção jurídico-constitucional de serviço público e com o regime jurídicoadministrativo de proteção dos seus usuários.

Dessa forma, tem-se que determinadas normas do CDC - como o já citado art. 22, que elenca como obrigação das empresas concessionárias ou permissionárias o fornecimento de "serviços adequados, eficientes, seguros e, quanto aos essenciais, contínuos" - constituem-se como um reforço legislativo que incrementa o regime jurídico-administrativo no sentido de possibilitar a efetivação, na maior medida possível, dos direitos fundamentais sociais concretizados por meio de serviços públicos. Como visto no primeiro tópico, é possível se extrair do texto constitucional até mesmo a existência de um direito fundamental ao serviço público adequado. Nessa linha, não há como se negar que o art. 22 do CDC é aplicável a qualquer relação de serviço público, uma vez que passa sem qualquer dificuldade pelo exercício da filtragem constitucional.

Ronaldo Porto Macedo Júnior afirma que existem diversos outros dispositivos do CDC que veiculam normas que indiscutivelmente possuem um conteúdo de Direito Administrativo, por tratarem especificamente de serviços públicos. A função dessas normas, portanto, "é garantir

\footnotetext{
${ }^{65}$ SCHIER, Paulo Ricardo. Novos Desafios da Filtragem Constitucional no Momento do Neoliberalismo. Revista Eletrônica de Direito do Estado, Salvador, n. 4, outubro/novembro/dezembro, 2005. Disponível na Internet em: <http://www.direitodoestado.com/revista/rede-4-outubro-2005-paulo\%20schier.pdf >. Acesso em 18 de julho de 2015. p. 2.

${ }^{66} \mathrm{O}$ constitucionalista paranaense é o responsável pelo pioneiro desenvolvimento dessa noção no direito brasileiro. Para uma análise mais aprofundada dessa temática, Cf. SCHIER, Paulo Ricardo. Filtragem Constitucional: construindo uma nova dogmática jurídica. Porto Alegre: Sérgio Antonio Fabris Editor, 1999.
} 
a defesa do consumidor usuário, ampliando o grau de participação qualitativa deste". Dispositivos com essa natureza também, evidentemente, passam pelo filtro constitucional com facilidade, podendo ser aplicados sem grandes problemas às relações de serviços público. Diante desse contexto, a proposta de Macedo Júnior é a de que o Código de Defesa do Consumidor se transforme "em mais um mecanismo de garantia e controle de accountability, transparência e responsabilidade dos administradores públicos envolvidos no fornecimento de serviços públicos". ${ }^{67}$

Um exemplo mais concreto que pode ser citado é a questão da inversão do ônus da prova, regra incidente nos casos judiciais envolvendo relações consumeristas, conforme disposição do art. $6^{\circ}$, VIII, do CDC. Os usuários de serviços públicos vivenciam uma vulnerabilidade técnica em relação à empresa concessionária prestadora do serviço muito semelhante àquela existente entre o consumidor e o fornecedor. Diante isso, a Lei de Concessão e Permissão de Serviço Público elenca, em seu art. $7^{\circ}$, II, o direito dos usuários de "receber do poder concedente e da concessionária informações para a defesa de interesses individuais ou coletivos", dispositivo que, por si só, já torna possível a defesa da inversão do ônus da prova nos casos envolvendo relações de serviço público.

No entanto, é inegável que a inversão ordenada pelo CDC é muito mais conhecida (e, portanto, aplicada) do que a dimensionada pela Lei de Concessão e Permissão de Serviço Público (Lei $\mathrm{n}^{\circ}$ 8.987/95). Dessa forma, já que isso é integralmente compatível com as noções constitucionais do regime jurídico dos serviços públicos e de uma Administração Pública inclusiva - que visa a aumentar a tutela da esfera jurídica dos cidadãos - não há necessidade de se pleitear a inversão pela Lei ${ }^{\circ}$ 8.987/95 - o que, provavelmente, obteria menos sucesso do que se fundamentasse o pedido no CDC, hipótese jurídica já pacificamente aceita em todos os tribunais. Com isso, realiza-se, nas palavras de César Guimarães Pereira, uma "alusão elíptica ao regime público: 'aplica-se' a inversão do ônus da prova com base no art. 6, VIII, do CDC [...] porque é mais simples do que se formular o raciocínio próprio, baseado no regime de Direito Público, que leva ao mesmo resultado". ${ }^{6}$

Esses são apenas alguns exemplos de situações nas quais se pode perceber que a aplicação de determinadas normas do CDC é legitimada pela filtragem constitucional. Nesses casos, o CDC serve como um auxílio ao usuário de serviço público, desprovido de legislação específica que regulamente sua proteção jurídica. É de se frisar, porém, a impossibilidade de se realizar uma listagem absoluta de todos os dispositivos do CDC que seriam aplicáveis às relações de serviço público. Na maioria dos casos, a legitimidade da aplicação só poderá ser analisada no caso concreto, quando, à luz das condições fáticas e jurídicas daquele contexto, o juiz poderá determinar se o dispositivo do CDC que se pretende aplicar a uma relação de serviço público é compatível com o filtro constitucional.

\section{OS LIMITES À UTILIZAÇÃO INDISCRIMINADA DO CDC AOS SERVIÇOS PÚBLICOS: CASOS DE INAPLICABILIDADE EM FACE DE ÓBICES CONSTITUCIONAIS}

Segundo Celso Antônio Bandeira de Mello, os serviços públicos são públicos exatamente porque o Estado, em dado local e tempo histórico, com o objetivo de prestar aos cidadãos determinadas utilidades ou comodidades materiais, assume-os como próprios, "por serem reputadas [as atividades ou comodidades] imprescindíveis, necessárias ou apenas

\footnotetext{
${ }^{67}$ MACEDO JÚNIOR, Ronaldo Porto. A proteção dos usuários de serviços públicos: a perspectiva do Direito do Consumidor. Revista Direito do Consumidor, São Paulo, ano 10, n. 37, p. 77-91, jan./mar. 2001. p. 89-91.

${ }^{68}$ PEREIRA, César A. Guimarães. Usuários de serviços públicos... Op. Cit. p. 232.

Revista de Direito Brasileira | São Paulo, SP | v. 15 | n. 6 | p. 311 - 336 | set./dez. 2016
} 
correspondentes a conveniências básicas da sociedade". ${ }^{69}$ Isto é, os serviços públicos não se configuram como uma atividade econômica comum, sujeita à livre vontade do empresário e desconexa de um sistema coletivo de prestação. Já por estes motivos é possível perceber que o CDC não poderá sempre ser aplicado a casos envolvendo relações de serviços públicos. Essa não é sua função principal. Seu objetivo primordial é outro: regulamentar juridicamente as relações consumeristas. Em razão disso, é evidente que boa parte de suas normas não são aplicáveis às relações de serviço público por esbarrarem em óbices constitucionais.

De fato, os serviços públicos têm um objetivo muito diferente das atividades econômicas privadas: a satisfação do interesse público, por meio da concretização dos direitos fundamentais dos cidadãos (encarados como membros de uma coletividade). ${ }^{70^{3}}$ Nessa lógica, o lucro - das empresas concessionárias ou da própria Administração Pública - advindo da prestação de serviços públicos deve se submeter ao imperativo do interesse público. Assim, é lógico defender que, por respeito à coletividade, as receitas advindas das tarifas pagas pelos usuários devam ser investidas em retorno às necessidades exigidas para manutenção e otimização do serviço público em questão. ${ }^{71}$

Por esses motivos, não se deve diante desse contexto adotar qualquer solução absoluta quanto à aplicabilidade do CDC: não estão corretas aquelas posições que negam por completo a aplicação das normas consumeristas às relações de serviços público, nem aquelas que "reputam os serviços prestados mediante remuneração (especialmente os concedidos, remunerados por tarifa) submetidos a um suposto regime de direito privado e equiparáveis a serviços prestados por particulares em seu próprio interesse". ${ }^{72}$ A posição adequada sobre a incidência do CDC às relações de serviço público é a de que as normas do Código de Defesa do Consumidor podem ser aplicadas à prestação de serviços públicos, desde que: (i) sejam compatíveis com a natureza dessas atividades; e (ii) passem pelo filtro constitucional, não esbarrando em obstáculos constitucionais que impeçam a aplicação das disposições consumeristas no campo dos serviços públicos.

Nesse sentido, o importante é buscar compreender quais normas do CDC podem e devem ser aplicadas às relações de serviço público e quais não. Como no tópico anterior já se tratou das situações e do método que torna possível a aplicação extensiva do CDC, cumpre agora analisar algumas hipóteses em que a aplicação das normas consumeristas às relações de serviço público não se demonstra adequada por não passar pelo filtro constitucional antes aludido.

Lembre-se, inicialmente, que os serviços públicos podem ser considerados um instrumento de coesão social e de redução das desigualdades, auxiliando a cumprir, desse modo, a disposição do art. $3^{\circ}$, III, da Constituição Federal. ${ }^{73}$ Como exemplo disso pode-se citar a "distribuição de renda" que é realizada por meio do pagamento de valores extras nas tarifas dos usuários que já usufruem de determinado serviço público, para que possa ser garantida a expansão desse serviço aos cidadãos que ainda não tem acesso a ele. Floriano de Azevedo Marques Neto, tratando desse assunto, diferencia o consumidor efetivo do consumidor potencial, em classificação que merece destaque. Em sua visão, "consumidor efetivo é aquele que frui o serviço público, porquanto está integrado na relação contratual travada com o fornecedor. Já o

\footnotetext{
${ }^{69}$ MELLO, Celso Antônio Bandeira de. Curso de Direito Administrativo. 31. ed. São Paulo: Malheiros, 2014. p. 692-693.

${ }^{70}$ Para uma análise mais específica acerca do conceito e do conteúdo jurídico de "interesse público", ver: HACHEM, Daniel Wunder. A dupla noção jurídica de interesse público em Direito Administrativo. A\&C - Revista de Direito Administrativo \& Constitucional, Belo Horizonte, ano 11, n. 44, p. 59-110, abr./jun. 2011.

${ }^{71}$ DERANI, Cristiane. Privatização e serviços públicos... Op. Cit. p. 73.

${ }_{73}^{72}$ PEREIRA, César A. Guimarães. Usuários de serviços públicos... Op. Cit. p. 134.

${ }^{73}$ Constituição da República Federativa do Brasil: "Art. $3^{\circ}$. Constituem objetivos fundamentais da República Federativa do Brasil: (...) III - erradicar a pobreza e a marginalização e reduzir as desigualdades sociais e regionais".
} 
potencial é aquele que não está incluído em uma tal relação, mas que o ordenamento regulatório 'quer' que ele venha a beneficiar-se do serviço". ${ }^{7}$

Diante desse contexto, o sistema regulatório dos serviços públicos se estrutura a fim de criar condições de tornar o consumidor (ou usuário, conforme conceituação defendida acima) potencial em efetivo. O sistema de cobrança extra de valores nas tarifas dos usuários efetivos é, afinal, um exemplo disso. Nesses casos, o usuário efetivo suporta o peso da integração e da coesão social - por meio do pagamento de valores extras - para que o usuário potencial também possa passar a usufruir do determinado serviço. É o chamado sistema de subsídios cruzados, no qual o Poder Público faz com que um grupo de usuários - normalmente os detentores de maior poder aquisitivo - arque com parte dos custos da prestação dos serviços aos usuários mais carentes.

Com isso, fica evidente o espírito solidário do sistema de prestação de serviços públicos - o que é perfeitamente aceitável (e, inclusive, esperável) de um Estado Social de Direito. No entanto, se analisado apenas através das lentes consumeristas, esse fenômeno poderia ser considerado abusivo, por violar normas expressas do CDC (como o art. 39, V, e o art. 51, IV), ${ }^{75}$ ao impor aos usuários o pagamento de tarifas cujo valor supera aquele individualmente fruído. ${ }^{76}$ Portanto, esses são dispositivos que, em razão das finalidades impostas pela Constituição ao sistema de prestação de serviço público, não poderiam ser utilizados como fundamento jurídico com o intuito de livrar os usuários efetivos de alto poder aquisitivo do pagamento dos valores extras que servem à inclusão dos usuários potenciais.

Além disso, como já anotado anteriormente, não se pode defender que a concessão de serviços públicos - hipótese que transfere o dever de prestação a um particular - igualaria o regime jurídico destes ao conferido às relações de consumo, permitindo a tal aplicabilidade indiscriminada. Ainda nesses casos mantém-se uma diferença, que reside no fato de que, embora em regime de concessão, a titularidade do serviço público - e, portanto, a responsabilidade última por sua prestação - continua sendo da Administração Pública. Já nas relações de consumo, o Poder Público exerce apenas uma função de "protetor" do consumidor hipossuficiente.

Nesse sentido, caso se admitisse a redução da tarifa por má qualidade do serviço - como o faz o CDC, em seu art. 20, III $-{ }^{77}$ estar-se-ia admitindo ou a própria ineficiência da Administração, ao prestar um serviço de modo inadequado, ou da política de concessões. No caso de má prestação por uma empresa concessionária, adverte Dinorá Adelaide Musetti Grotti que a solução mais correta seria a de buscar, junto à respectiva agência reguladora do serviço - se existente, obviamente - as devidas sanções aplicáveis, no sentido de diligenciar a empresa concessionária a cumprir com as obrigações contratuais assumidas - entre elas, a de prestação

\footnotetext{
74 MARQUES NETO, Floriano de Azevedo. A Nova Regulação dos Serviços Públicos. Revista de Direito Administrativo, Rio de Janeiro, ano 58, n. 228, p. 13-29, abr./jun. 2002. p. 28-29. Também defendendo que o ordenamento jurídico deve levar em consideração os usuários potenciais e suas necessidades, Juan Carlos Cassagne afirma que "el concepto de usuario no puede limitarse al usuario actual sino que el concepto protectorio debe comprender al usuario potencial o futuro en base a criterios de equidad intergeneracional." CASSAGNE, Juan Carlos. Los nuevos derechos y garantías. Revista de Investigações Constitucionais, Curitiba, vol. 3, n. 1, p. 59-108, jan./abr. 2016. p. 76.

${ }^{75}$ Código de Defesa do Consumidor: “Art. 39. É vedado ao fornecedor de produtos ou serviços, dentre outras práticas abusivas: (...) $V$ - exigir do consumidor vantagem manifestamente excessiva. (...) Art. 51. São nulas de pleno direito, entre outras, as cláusulas contratuais relativas ao fornecimento de produtos e serviços que: (...) $I V$ estabeleçam obrigações consideradas iníquas, abusivas, que coloquem o consumidor em desvantagem exagerada, ou sejam incompatíveis com a boa-fé ou a equidade".

${ }^{76}$ ARAGÃO, Alexandre Santos de. Direito dos serviços públicos... Op. Cit. p. 496; 498.

${ }^{77}$ Código de Defesa do Consumidor: “Art. 20. O fornecedor de serviços responde pelos vícios de qualidade que os tornem impróprios ao consumo ou lhes diminuam o valor, assim como por aqueles decorrentes da disparidade com as indicações constantes da oferta ou mensagem publicitária, podendo o consumidor exigir, alternativamente e à sua escolha: (...) III - o abatimento proporcional do preço".
}

Revista de Direito Brasileira | São Paulo, SP | v. 15 | n. 6 | p. 311 - 336 | set./dez. 2016 
adequada e eficiente do serviço. ${ }^{78}$ Eis, portanto, mais um dispositivo do CDC que não é compatível com os princípios constitucionais que regem a atividade da Administração Pública e dos agentes privados que com ela firmam parcerias.

Cabe ressaltar, ainda, mais um exemplo de manifesta inaplicabilidade das normas consumeristas às relações de serviço público: ao tratar "da defesa do consumidor em juízo", o CDC, em seu art. 82, II e III, elenca como legitimados ativos para a propositura de ação judicial que vise a combater uma violação a direitos difusos, coletivos ou individuais homogêneos a União, os Estados, os Municípios e o Distrito Federal e as entidades e órgãos da Administração Pública, direta ou indireta. Evidentemente, esse dispositivo não se pode aplicar às relações advindas de serviços públicos não concedidos. É completamente ilógico imaginar que a Administração Pública pudesse propor uma ação judicial contra si mesma. Dessa forma, essa norma é mais um exemplo de dispositivo que, no contexto apontado, não pode ser aplicado às relações de serviço público.

Há, ainda, algumas normas do CDC que se aplicam a determinados serviços públicos e a outros não. É o caso do art. 39, I, ${ }^{79}$ que proíbe a venda casada. Em algumas situações, como nas de fornecimento de serviço público de água e esgoto, é aceitável, por questões de funcionalidade prática, que se exija que todo usuário de serviço de abastecimento de água esteja também ligado à rede de coleta de esgoto. Trata-se, de fato, de serviços distintos; no entanto, como são prestados sempre por apenas um fornecedor, não há qualquer espaço para se defender a aplicabilidade da referida norma do CDC. Por outro lado, todavia, pode-se citar como exemplo o setor das telecomunicações, no qual seria ilegal a obrigatoriedade de compra conjunta do serviço de telefonia e de internet, por se tratar de um âmbito no qual há maior liberdade de atuação das empresas prestadoras e porque não há nenhum motivo prático que justifique a indispensabilidade da venda conjunta desses serviços.

Como já aludido no fim do tópico anterior, a análise da aplicabilidade das normas do CDC às relações de serviço público depende muito das condições fático-jurídicas do caso concreto. Pode ser que um dispositivo, em determinada situação, não passe pelo filtro constitucional do regime jurídico-administrativo e que, em outro contexto, sua aplicação esteja em plena conformidade com as normas constitucionais. Assim, os casos acima expostos não são exaustivos. O objetivo dessa tratativa era apenas demonstrar como em certas ocasiões algumas normas do CDC não podem ser aplicadas às relações de serviço público, seja porque contrariariam dispositivos constitucionais, seja porque sua aplicação seria manifestamente ilógica.

\section{CONCLUSÕES}

Diante do exposto, cumpre apresentar as conclusões obtidas no desenvolvimento do presente estudo:

1. O cidadão usuário de serviços públicos não deve ser compreendido como um "consumidor-cliente" do Estado. O consumidor é uma figura típica das relações jurídicas travadas na esfera da economia de mercado (nos termos do art. 170, V, da Constituição, que situa a defesa do consumidor entre os princípios da ordem econômica), que terá acesso aos produtos e serviços por meio de uma contraprestação pecuniária, marcada pela onerosidade, tendo como uma de suas características a vulnerabilidade em face do fornecedor. Nos termos do CDC, ele será o destinatário final do produto ou serviço. Já o usuário de serviços públicos será toda a pessoa que, a título gratuito ou oneroso, usufrua de serviços cujo fornecimento incumba ao Poder

\footnotetext{
${ }^{78}$ GROTTI, Dinorá Adelaide Musetti. O serviço público e a Constituição brasileira de 1988... Op. Cit. p. 352.

${ }^{79}$ Código de Defesa do Consumidor: “Art. 39. É vedado ao fornecedor de produtos ou serviços, dentre outras práticas abusivas: $I$ - condicionar o fornecimento de produto ou de serviço ao fornecimento de outro produto ou serviço, bem como, sem justa causa, a limites quantitativos".
}

Revista de Direito Brasileira | São Paulo, SP | v. 15 | n. 6 | p. 311 - 336 | set./dez. 2016 
Público (mediante prestação direta ou indireta), ainda que não seja o destinatário final, mesmo que não ostente a característica da vulnerabilidade, muitas vezes sem ter a liberdade de escolha do fornecedor em razão da exclusividade da titularidade do serviço pelo Estado. Essa diferenciação, contudo, não é decisiva para se determinar a aplicabilidade ou não do CDC aos usuários de serviços públicos, uma vez que a própria legislação contém dispositivos que tratam expressamente da prestação de serviços públicos.

2. No Direito brasileiro, a posição mais adequada quanto à aplicabilidade do CDC nas relações que envolvem prestação de serviços públicos é aquela que admite que estes sejam regidos tanto por normas de Direito Público (v.g.: Lei $\mathrm{n}^{\circ}$ 8.987/95, conhecida como Lei de Concessões de Serviços Públicos), quanto por normas de Direito do Consumidor, já que as próprias leis de Direito Público fazem remissão à aplicação do CDC ou à defesa dos interesses do consumidor (v.g.: art. $7^{\circ}$ da Lei $\mathrm{n}^{\circ}$ 8.987/95; art. $5^{\circ}$ da Lei $\mathrm{n}^{\circ}$ 9.472/97 - Lei das Telecomunicações; art. $1^{\circ}$, III da Lei $n^{\circ}$ 9.478/97 - Política Energética Nacional) e o próprio CDC tem previsões específicas que se aplicam expressamente à prestação de serviços públicos (v.g.: art. $6^{\circ}, \mathrm{X}$; art. 22, caput).

3. A superação da dicotomia Direito Público versus Direito Privado a partir da constitucionalização do Direito impede que o critério de aplicação ou não do CDC a uma relação jurídica seja a sua caracterização como privada ou pública. Se a Constituição assegura tanto o direito fundamental à proteção e defesa do consumidor (art. $5^{\circ}$, XXXII) quanto o direito fundamental ao serviço público adequado (art. $5^{\circ}, \S 2^{\circ}$, c/c art. 175, parágrafo único, IV), e se ambos os regimes jurídicos - de Direito Administrativo e de Direito do Consumidor - se destinam à tutela reforçada do cidadão hipossuficiente frente a um ente prestador de serviços, o que deve terminar a incidência do CDC sobre os serviços públicos é a existência de normas protetivas ao usuário nesse diploma normativo e a sua compatibilidade com a lógica dos serviços públicos. Por isso, na ausência de uma lei de proteção do usuário de serviços públicos, deve-se aceitar a aplicabilidade daquelas normas do CDC que passem pela filtragem constitucional e sejam compatíveis com a racionalidade do regime jurídico-administrativo.

4. O que define a incidência do CDC nos serviços públicos não é a existência de uma relação consumerista ou não, de modo que mesmo os serviços que não são remunerados individualmente por tarifa podem se submeter às normas do CDC. Restringir a aplicação do CDC aos serviços públicos em que há contraprestação individualizada do serviço por meio de tarifa e àqueles nos quais o usuário tem liberdade de escolher o prestador (casos em que não há exclusividade), afastando a sua incidência dos serviços públicos gratuitos, dos serviços não remunerados de forma singularizada por taxas e tarifas e daqueles ofertados apenas pelo Estado ou por único concessionário, geraria um paradoxo: em face da inexistência de uma Lei de Proteção dos Usuários dos Serviços Públicos, essa posição implicaria aceitar uma tutela jurídica mais robusta aos usuários de serviços públicos concedidos a empresas privadas do que aquela atribuída aos cidadãos usuários de serviços ofertados diretamente pelo Estado.

5. A aceitação da incidência do CDC sobre a prestação de serviços públicos não significa admitir que a lei, em sua integralidade, aplica-se a essas relações. Há determinadas normas do CDC que incidem sobre os serviços públicos e outras disposições que não incidem. Aplicam-se aquelas que, passando pelo filtro constitucional, são compatíveis com a lógica dos serviços públicos. É o caso do art. 22, que exige a prestação de serviços eficientes, seguros e contínuos, e do art. $6^{\circ}$, VIII, que estabelece a inversão do ônus da prova em casos de hipossuficiência. Não sobrevivem à filtragem constitucional, todavia, as normas do CDC que se revelem incompatíveis com a lógica do serviço público e com os princípios e regras que integram o regime jurídico específico dos serviços públicos.

\section{REFERÊNCIAS}


ALMEIDA, João Batista de. A proteção jurídica do consumidor. 4. ed. São Paulo: Saraiva, 2003.

AMAR, Jacques. De l'Usager au Consomatteur de Service Public. Aix-en-Provence: Presses Universitaires d'AixMarseille - PUAM, 2001.

ARAGÃO, Alexandre Santos de. Direito dos serviços públicos. 3. ed. Rio de Janeiro: Forense, 2013.

ARAÚJO PINTO, Cristiano Paixão. Arqueologia de uma distinção: o público e o privado na experiência histórica do direito: In: PEREIRA, Cláudia Fernanda de Oliveira (Org.). O novo direito administrativo brasileiro: o Estado, as agências e o terceiro setor. Belo Horizonte: Fórum, 2003.

BACELlAR FILHO, Romeu Felipe. A Administração Pública entre o Direito Público e o Direito Privado. Revista de Direito Civil Contemporâneo, São Paulo, v. 3, n. 2, p. 31-53, abr./jun. 2015.

BACELLAR FILHO, Romeu Felipe. Dignidade da pessoa humana, direitos fundamentais e Direito Administrativo. Revista Eurolatinoamericana de Derecho Administrativo, Santa Fe, vol. 1, n. 2, p. 247-254, jul./dic. 2014.

BACELLAR FILHO, Romeu Felipe. Direito administrativo e o novo Código Civil. Belo Horizonte: Fórum, 2007.

BALBÍN, Carlos F. Un Derecho Administrativo para la inclusión social. A\&C-Revista de Direito Administrativo \& Constitucional, Belo Horizonte, ano 14, n. 58, p. 33-59, out./dez. 2014.

BELEM, Bruno Moraes Faria Monteiro. A concessão administrativa nos serviços de relevância social. A\&C Revista de Direito Administrativo \& Constitucional, Belo Horizonte, ano 11, n. 44, p. 165-190, abr./jun. 2011.

BRESSER PEREIRA, Luiz Carlos. Reforma do Estado para a cidadania: a reforma gerencial brasileira na perspectiva internacional. São Paulo: Editora 34, 2002.

BUCCI, Maria Paula Dallari. Direito administrativo e políticas públicas. São Paulo: Saraiva, 2002.

CASSAGNE, Juan Carlos. La Intervención Administrativa. 2. ed. Buenos Aires: Abeledo-Perrot, 1994.

CASSAGNE, Juan Carlos. Los nuevos derechos y garantías. Revista de Investigações Constitucionais, Curitiba, vol. 3, n. 1, p. 59-108, jan./abr. 2016.

CHILLON, Sandie. De l'Usager au Consommateur: une évolution de l'ouverture du service public à la concurrence? In: HÉNAFF, Gael (Org.). Concurrence et Services Publics: enjeux et perspectives. Rennes: Presses Universitaires de Rennes - PUR, 2002.

COSTA, Regina Helena. A tributação e o consumidor. Revista do Instituto de Pesquisas e Estudos - Divisão Jurídica, Bauru, ano 32, n. 17, p. 217-227, abr./jun. 1997.

CUÉLLAR, Leila. Serviço de abastecimento de água e a suspensão do fornecimento. Revista de Direito Público da Economia - RDPE, Belo Horizonte, ano 1, n. 3, p. 131-159, jul/set. 2003.

CORVALÁN, Juan Gustavo. Transformações do "regime de Direito Administrativo" - A propósito do regime exorbitante e das prerrogativas da Administração Pública. A\&C - Revista de Direito Administrativo \& Constitucional, Belo Horizonte, ano 13, n. 51, p. 49-73, jan./mar. 2013.

DAL POZZO, Augusto Neves. Aspectos fundamentais do serviço público no Direito brasileiro. São Paulo: Malheiros, 2012.

DELPIAZZO, Carlos E. Centralidad del administrado en el actual Derecho Administrativo: impactos del Estado Constitucional de Derecho. Revista de Investigações Constitucionais, Curitiba, vol. 1, n. 3, p. 7-32, set./dez. 2014.

DERANI, Cristiane. Privatização e serviços públicos: as ações do Estado na produção econômica. São Paulo: Max Limonad, 2002.

DI PIETRO, Maria Sylvia Zanella. Direito Administrativo e dignidade da pessoa humana. A\&C-Revista de Direito Administrativo \& Constitucional, Belo Horizonte, ano 13, n. 52, p. 13-33, abr./jun. 2013. 
DOMINGUEZ, Guilherme Diniz de Figueiredo. A interrupção no fornecimento dos serviços públicos de energia elétrica e água, por inadimplência dos usuários, à luz da jurisprudência dos tribunais superiores (STJ e STF). Revista de Direito Público da Economia, Belo Horizonte, ano 6, n. 24, p. 219-236, out./dez. 2008.

DUARTE JÚNIOR, Ricardo César Ferreira. A legitimidade do Estado regulador brasileiro: uma análise democrática. A\&C-Revista de Direito Administrativo \& Constitucional, Belo Horizonte, ano 11, n. 43, p. 135-166, jan./mar. 2011.

GABARDO, Emerson. Interesse público e subsidiariedade: o Estado e a sociedade civil para além do bem e do mal. Belo Horizonte: Fórum, 2009.

FALLA, Fernando Garrido. Tratado de Derecho Administrativo. 9. ed. Madrid: Ed. Tecnos, 1985.

FARIA, Luzardo. A suspensão do fornecimento de serviço público essencial por inadimplemento do usuário: o interesse público entre eficiência e dignidade. In: BLANCHET, Luiz Alberto; HACHEM, Daniel Wunder; SANTANO, Ana Cláudia (Coords.). Eficiência e Ética na Administração Pública. Curitiba: Editora Íthala, 2015. p. 109-134.

FRAGA, Gabino. Derecho Administrativo. 8. ed. Cidade do México: Ed. Porruá, 1960.

GASTALDI, José Pretelli. Elementos de economia política. 17. ed. São Paulo: Saraiva, 1999.

GRAU, Eros Roberto. A ordem econômica da Constituição de 1988: interpretação e crítica. 14. ed. São Paulo: Malheiros, 2010.

GROTTI, Dinorá Adelaide Musetti. O serviço público e a Constituição brasileira de 1988. São Paulo: Malheiros Editores, 2003.

HACHEM, Daniel Wunder. A dupla noção jurídica de interesse público em Direito Administrativo. A\&C - Revista de Direito Administrativo \& Constitucional, Belo Horizonte, ano 11, n. 44, p. 59-110, abr./jun. 2011.

HACHEM, Daniel Wunder. Direito fundamental ao serviço público adequado e capacidade econômica do cidadão: repensando a universalidade do acesso à luz da igualdade material. A\&C-Revista de Direito Administrativo \& Constitucional. Belo Horizonte, ano 14, n. 55, p. 123-158, jan./mar. 2014.

JUSTEN FILHO, Marçal. Curso de Direito Administrativo. 9. ed. rev. e atual. São Paulo: Editora Revista dos Tribunais, 2013.

JUSTEN FILHO, Marçal. Teoria geral das concessões de serviço público. São Paulo: Dialética, 2003.

LEAL, Rogério Gesta. O problema de prestação de serviço público essencial enquanto Direito Social Fundamental e sua contraprestação em face da incapacidade financeira do usuário. In: LEAL, Rogério Gesta. Condições e possibilidades eficaciais dos direitos fundamentais sociais: os desafios do Poder Judiciário no Brasil. Porto Alegre: Livraria do Advogado, 2009. p. 135-149

LUCCA, Newton. Direito do Consumidor. São Paulo: Quartier Latin, 2003. 
MACEDO JÚNIOR, Ronaldo Porto. A proteção dos usuários de serviços públicos: a perspectiva do Direito do Consumidor. Revista Direito do Consumidor, São Paulo, ano 10, n. 37, p. 77-91, jan./mar. 2001.

MARQUES NETO, Floriano de Azevedo. A Nova Regulação dos Serviços Públicos. Revista de Direito Administrativo, Rio de Janeiro, ano 58, n. 228, p. 13-29, abr./jun. 2002.

MARQUES, Cláudia Lima. Contratos no Código de Defesa do Consumidor. 4. ed. São Paulo: Editora Revista dos Tribunais, 2002.

MARQUES, Cláudia Lima; BENJAMIN, Antônio Herman V; MIRAGEM, Bruno. Comentários ao Código de Defesa do Consumidor. 2. ed. rev., atual. e ampl. São Paulo: Editora Revista dos Tribunais, 2006.

MARTíNEZ, Augusto Durán. Estado Constitucional de Derecho y servicios públicos. A\&C - Revista de Direito Administrativo \& Constitucional, Belo Horizonte, ano 15, n. 60, p. 39-62, abr./jun. 2015.

MARTINS, Ricardo Marcondes. Regulação administrativa à luz da Constituição Federal. São Paulo: Malheiros, 2011.

MELLO, Celso Antônio Bandeira de. Curso de Direito Administrativo. 31. ed. São Paulo: Malheiros, 2014.

MELLO, Celso Antônio Bandeira de. Serviço público e sua feição constitucional no Brasil. In: CIENFUEGOS SALGADO, David; LÓPEZ OLVERA, Miguel Alejandro (Coords.). Estudios en homenaje a Don Jorge Fernández Ruiz: responsabilidad, contratos y servicios públicos. México: Universidad Autónoma de México, 2005.

MELLO, Celso Antônio Bandeira de. Prestação de serviços públicos e administração indireta. 2. ed. São Paulo: Revista dos Tribunais, 1983.

MOURA, Emerson Affonso da Costa. O Estado gerencial, regulação econômica e serviços públicos - O papel das agências na promoção do desenvolvimento. A\&C - Revista de Direito Administrativo \& Constitucional, Belo Horizonte, ano 14, n. 57, p. 193-217, jul./set.. 2014.

NUSDEO, Fábio. Curso de economia: introdução ao Direito Econômico. São Paulo: Revista dos Tribunais, 1997.

PASQUALOTTO, Adalberto. Os serviços públicos no Código de Defesa do Consumidor. Revista Direito do Consumidor, São Paulo, ano. 1, n. 1, jan./mar. p. 130-148. 1992.

PAUlA, Adriano Perácio de. O Código do Consumidor e o princípio da continuidade dos serviços públicos comerciais e industriais. Revista de Informação Legislativa, Brasília, ano 30, n. 118, p. 403-414, abr./jun. 1993.

PEREIRA, César A. Guimarães. Usuários de serviços públicos: usuários, consumidores e os aspectos econômicos dos serviços públicos. São Paulo: Saraiva, 2006.

PERLINGIERI, Pietro. Perfis do direito civil: uma introdução ao direito civil constitucional. 2. ed. Rio de Janeiro: Renovar, 2002.

RACHLINE, François. Services Publics, Économie de Marché. Paris: Presses de Sciences Po, 1996.

RODRÍGUEZ-ARANA MUÑOZ, Jaime. El derecho fundamental a la buena Administración. Revista Eurolatinoamericana de Derecho Administrativo, Santa Fe, vol. 1, n. 2, p. 73-93, jul./dic. 2014.

SACRISTÁN, Estela. Gestión eficiente y ética en la efectivización de los servicios públicos relativos a derechos sociales. Revista de Investigações Constitucionais, Curitiba, vol. 3, n. 1, p. 125-143, jan./abr. 2016.

SALOMONI, Jorge Luis. Teoría General de los Servicios Públicos. Buenos Aires: Ed. Ad-Hoc, 1999.

SCHIER, Paulo Ricardo. Filtragem Constitucional: construindo uma nova dogmática jurídica. Porto Alegre: Sérgio Antonio Fabris Editor, 1999.

SCHIER, Paulo Ricardo. Novos Desafios da Filtragem Constitucional no Momento do Neoliberalismo. Revista Eletrônica de Direito do Estado, Salvador, n. 4, outubro/novembro/dezembro, 2005. Disponível na Internet em: 
<http://www.direitodoestado.com/revista/rede-4-outubro-2005-paulo\%20schier.pdf>. Acesso em 18 de julho de 2015 .

SCHIRATO, Vitor Rhein. Livre iniciativa nos serviços públicos. Belo Horizonte: Fórum, 2012.

SILVA, Cristina Alves da; NELSON, Rocco Antonio Rangel Rosso. Agências reguladoras e evolução estatal - Uma análise temporal do papel do Estado no setor econômico. A\&C-Revista de Direito Administrativo \& Constitucional, Belo Horizonte, ano 13, n. 51, p. 49-73, jan./mar. 2013.

SOUTO, Marcos Juruena Villela. Direito Administrativo da Economia. Rio de Janeiro: Lumen Juris, 2003. 